\title{
Biogeochemical and biological impacts of diazotroph blooms in a low-nutrient, low-chlorophyll ecosystem: synthesis from the VAHINE mesocosm experiment (New Caledonia)
}

\author{
Sophie Bonnet ${ }^{1,2}$, Melika Baklouti ${ }^{1}$, Audrey Gimenez ${ }^{1}$, Hugo Berthelot ${ }^{1}$, and Ilana Berman-Frank ${ }^{3}$ \\ ${ }^{1}$ IRD, Aix Marseille Université, CNRS/INSU, Université de Toulon, Mediterranean Institute of Oceanography (MIO) \\ UM110, 13288, Marseille-Noumea, France, New Caledonia \\ ${ }^{2}$ Institut de Recherche pour le Développement, AMU/ NRS/INSU, Université de Toulon, Mediterranean Institute \\ of Oceanography (MIO) UM110, 98848, Noumea, New Caledonia \\ ${ }^{3}$ Mina and Everard Goodman Faculty of Life Sciences, Bar-Ilan University, Ramat Gan, Israel
}

Correspondence to: Sophie Bonnet (sophie.bonnet@univ-amu.fr)

Received: 31 December 2015 - Published in Biogeosciences Discuss.: 23 February 2016

Revised: 21 May 2016 - Accepted: 23 May 2016 - Published: 10 August 2016

\begin{abstract}
In marine ecosystems, biological $\mathrm{N}_{2}$ fixation provides the predominant external source of nitrogen $(\mathrm{N}$; $140 \pm 50 \mathrm{Tg} \mathrm{Nyr}^{-1}$ ), contributing more than atmospheric and riverine inputs to the $\mathrm{N}$ supply. Yet the fate and magnitude of the newly fixed $\mathrm{N}$, or diazotroph-derived $\mathrm{N}$ (hereafter named DDN) in marine ecosystems is poorly understood. Moreover, whether the DDN is preferentially and directly exported out of the photic zone, recycled by the microbial loop and/or transferred into larger organisms remains unclear. These questions were investigated in the framework of the VAHINE (VAriability of vertical and tropHIc transfer of diazotroph derived $\mathrm{N}$ in the south wEst Pacific) project. Triplicate large volume $\left(\sim 50 \mathrm{~m}^{3}\right)$ mesocosms were deployed in the tropical south-west Pacific coastal ocean (New Caledonia). The mesocosms were intentionally fertilized with $\sim 0.8 \mu \mathrm{M}$ dissolved inorganic phosphorus (DIP) at the start of the experiment to stimulate diazotrophy. A total of 47 stocks, fluxes, enzymatic activities and diversity parameters were measured daily inside and outside the mesocosms by the 40 scientists involved in the project. The experiment lasted for 23 days and was characterized by two distinct and successive diazotroph blooms: a dominance of diatom-diazotroph associations (DDAs) during the first half of the experiment (days 2-14) followed by a bloom of unicellular cyanobacterial lineage $\mathrm{C}$ (UCYN-C during the second half of the experiment (days 15-23). These conditions provided a unique opportunity to compare the DDN transfer and export efficiency as-
\end{abstract}

sociated with different diazotrophs. Here we summarize the major experimental and modelling results obtained during the project and described in the VAHINE special issue, in particular those regarding the evolution of the main standing stocks, fluxes and biological characteristics over the 23-day experiment, the contribution of $\mathrm{N}_{2}$ fixation to export fluxes, the DDN released to dissolved pool and its transfer to the planktonic food web (bacteria, phytoplankton, zooplankton). We then apply our Eco3M modelling platform to further infer the fate of DDN in the ecosystem and the role of $\mathrm{N}_{2}$ fixation on productivity, food web structure and carbon export. Recommendations for future work are finally provided in the conclusion section.

\section{Introduction}

Atmospheric dinitrogen $\left(\mathrm{N}_{2}\right)$ is the largest pool of nitrogen $(\mathrm{N})$ on earth yet it is unavailable for most organisms that require $\mathrm{N}$ for growth. Biological fixation of $\mathrm{N}_{2}$ (or diazotrophy) is catalysed by the nitrogenase enzyme (encoded by the nifH genes) that converts the inert triplebond $\mathrm{N}_{2}$ into bioavailable ammonium $\left(\mathrm{NH}_{4}^{+}\right)$. This process has long been studied in terrestrial agriculture as it increases the yield of crops associated with diazotrophs. In the ocean, diazotrophy provides the predominant external source of $\mathrm{N}\left(140 \pm 50 \mathrm{Tg} \mathrm{N} \mathrm{yr}^{-1}\right)$ contributing more than at- 
mospheric and riverine inputs (Gruber, 2004). Moreover, $\mathrm{N}_{2}$ fixation acts as a natural fertilizer adding a source of new $\mathrm{N}$ that is available for non-diazotrophic primary producers and bacterioplankton especially in low-nutrient, low-chlorophyll (LNLC) ecosystems, where $\mathrm{N}$ is the proximal limiting nutrient (Moore et al., 2013). LNLC ecosystems include the vast oligotrophic subtropical gyres and represent more than $60 \%$ of the global ocean area. $\mathrm{N}_{2}$-fixing organisms have a competitive advantage and sustain a large percentage $(\sim 50 \%)$ of new primary production (PP; e.g. Karl et al., 2002) in these vast ecosystems.

The non-heterocystous filamentous cyanobacterium Trichodesmium spp. remains the most studied marine diazotroph. Based on direct rate measurements, Trichodesmium accounts for a quarter to half of geochemically derived estimates of marine $\mathrm{N}_{2}$ fixation at the global scale (Mahaffey et al., 2005). Diverse cyanobacteria and bacteria also fix $\mathrm{N}_{2}$ in marine waters. These include the following: (1) the heterocystous cyanobacteria frequently found in association with diatoms (diatom-diazotroph associations, hereafter referred to as DDAs; Foster and O'Mullan, 2008) efficient at exporting organic matter out of the photic zone (Karl et al., 2012), (2) unicellular cyanobacterial lineages (UCYN-A, B and C) with a size range from 1 to $6 \mu \mathrm{m}$ (Moisander et al., 2010), which are key oceanic diazotrophs (Luo et al., 2012) accounting for the predominant fraction of $\mathrm{N}_{2}$ fixation in many tropical oceans (Bonnet et al., 2009; Montoya et al., 2004) and (3) non-cyanobacterial $\mathrm{N}_{2}$-fixing bacteria and archaea that are still poorly characterized, yet recent studies show they are abundant and active across the world's oceans (Bonnet et al., 2013; Farnelid et al., 2011; Farnelid and Riemann, 2008; Moisander et al., 2014).

While the role and contribution of marine $\mathrm{N}_{2}$ fixation on biogeochemical cycles have been intensely investigated, a critical question that remains poorly studied is the fate of newly fixed $\mathrm{N}$, or diazotroph-derived $\mathrm{N}$ (hereafter named DDN) in LNLC ecosystems (Mulholland, 2007). It remains unclear whether the DDN is preferentially exported directly out of the photic zone, recycled by the microbial loop and/or transferred into larger organisms, subsequently enhancing indirect particle export.

This question was investigated in the framework of the VAHINE (VAriability of vertical and tropHIc transfer of diazotroph derived $\mathrm{N}$ in the south wEst Pacific) project. Here we summarize the major results described in the VAHINE special issue and integrate them to obtain general conclusions from the experiment. In this introduction, we first summarize some of our knowledge regarding the fate of DDN in the ocean, describe the ongoing technical challenges to study this question, and describe and the specific objectives of the VAHINE project.

\subsection{Current knowledge on the fate of DDN in the ocean}

\subsubsection{DDN release to the dissolved pool}

Diazotrophs release some of the recently fixed $\mathrm{N}_{2}$ as dissolved organic $\mathrm{N}(\mathrm{DON})$ and $\mathrm{NH}_{4}^{+}$to the surrounding waters (Glibert and Bronk, 1994; Meador et al., 2007; Mulholland et al., 2006). Several studies have reported elevated DON and $\mathrm{NH}_{4}^{+}$concentrations during and immediately after Trichodesmium spp. blooms in the Indian (Devassy et al., 1978, 1979; Glibert and O'Neil, 1999), Pacific (Karl et al., 1992, 1997b), and Atlantic (Lenes et al., 2001) oceans. Subsequent culture (Hutchins et al., 2007; Karl et al., 1992, 1997a) and field studies (Benavides et al., 2013b; Konno et al., 2010; Mulholland and Bernhardt, 2005) have quantified that diazotrophs release $\sim 50 \%$ of the total fixed $\mathrm{N}_{2}$ to the dissolved pool. Most of these studies were performed on the conspicuous Trichodesmium spp. and were based on the difference between gross $\mathrm{N}_{2}$ fixation (measured by acetylene reduction assays) and net $\mathrm{N}_{2}$ fixation (Mulholland et al., 2004) measured using the ${ }^{15} \mathrm{~N}_{2}$ labelling technique (Montoya et al., 1996). The recent modification of the ${ }^{15} \mathrm{~N}_{2}$ labelling method (Mohr et al., 2010) led to higher net $\mathrm{N}_{2}$ fixation rates and potentially reduced the gap between gross and net $\mathrm{N}_{2}$ fixation. Applying the new $\mathrm{N}_{2}$ fixation method and the direct measurement of the ${ }^{15} \mathrm{~N}$ signature on the released DON and $\mathrm{NH}_{4}^{+}$demonstrated limited release rates from Trichodesmium spp. and from three strains of UCYN-B and C $(<1 \%$ of total $\mathrm{N}_{2}$ fixation; Berthelot et al., 2015a). Similar experiments (examining the direct ${ }^{15} \mathrm{~N}$ measurement on released molecules) showed low release by UCYN-C ( $\sim 1 \%$; Benavides et al., 2013a). Culture studies probably represent lower end estimates of DDN release, as in the field, exogenous factors such as viral lysis (Hewson et al., 2004; Ohki, 1999) and sloppy feeding (O'Neil et al., 1996) may enhance the leakage of DDN by UCYN, yet such field studies on these organisms are rare.

\subsubsection{Transfer of DDN to the trophic chain and impact on plankton community composition}

The transfer of DDN towards the first levels of the food chain (phytoplankton, bacteria) is mainly achieved through the dissolved pool. Devassy et al. (1979) first observed that as blooms of Trichodesmium spp. decayed in the Indian ocean, diatom populations increased (mainly Chaetoceros sp.), followed by a succession of cladocerans, dinoflagellates, green algae and finally copepods. In the Atlantic, a large abundance of non-diazotrophic diatoms and dinoflagellates succeeded blooms of Trichodesmium spp. (Devassy et al., 1978; Furnas and Mitchell, 1996; Lenes et al., 2001), while in the pelagic waters of the Kuroshio current, Trichodesmium spp. and diatom abundance were positively correlated (Chen et al., 2011). These studies suggest a potential transfer of DDN from diazotrophic to non-diazotrophic phytoplankton. Ac- 
tual calculations of DDN transfer were first performed by Bronk et al. (2004), Lenes and Heil (2010) and Sipler et al. (2013), who demonstrated how the DDN released by Trichodesmium spp. affected the bloom dynamics of the toxic dinoflagellate Karenia brevis in the Gulf of Mexico. Results from size-fractionation of picoplankton after ${ }^{15} \mathrm{~N}_{2}$ incubations also supported the idea of a DDN transfer towards nondiazotrophic plankton (Bryceson and Fay, 1981; Olendieck et al., 2007; Garcia et al., 2007). Yet, this method could not discriminate the DDN transfer towards non-diazotrophic picoplankton from $\mathrm{N}_{2}$ fixation by picoplankton itself and thus likely overestimated the DDN transfer.

Thus, the actual transfer of DDN towards nondiazotrophic phytoplankton and bacteria remains poorly quantified and challenging due mainly to technical limitations as it requires appropriate methodologies to track the passage of DDN through the different components of microbial food web. Moreover, the planktonic groups (autotrophic vs. heterotrophic, small vs. large phytoplankton) that benefit the most from this DDN and develop during and/or after diazotroph blooms have not been identified so far despite their potential to differentially influence the structure of the trophic chain and eventually the mode of carbon (C) export from the photic zone.

Regarding higher trophic levels, low $\delta^{15} \mathrm{~N}$ signatures measured on zooplankton indicate that DDN is transferred towards secondary producers (Montoya et al., 2002b). This transfer can be direct, through the ingestion of diazotrophs (O'Neil et al., 1996; Wannicke et al., 2013), or indirect, i.e. mediated by the dissolved $\mathrm{N}$ released by diazotrophs (Capone et al., 1994; Glibert and Bronk, 1994; Mulholland et al., 2004). The dissolved N (both DIN and DON) is taken up by heterotrophic and autotrophic plankton and then potentially grazed on by zooplankton, yet these pathways remain poorly explored.

The transfer of DDN to zooplankton may possibly depend on the diazotroph community composition in the water column. Toxicity of Trichodesmium spp. (Kerbrat et al., 2010) combined with poor nutritional quality reduce grazing pressure by copepods other than several harpacticoids including Macrosetella gracilis (O'Neil, 1999; O'Neil and Roman, 1992). Stable isotope measurements performed on zooplankton suggest higher DDN uptake when the diazotroph community is dominated by DDAs rather than Trichodesmium spp. (Montoya et al., 2002a). Grazing experiments on UCYN have not been conducted so far and the potential of UCYN as a conduit of DDN into marine food webs remains unexplored.

\subsubsection{Export of DDN out of the photic zone}

Low $\delta^{15} \mathrm{~N}$ signatures in particles from sediment traps in the tropical north Pacific suggest that at least part of the DDN is ultimately exported out of the photic zone (Karl et al., 1997b, 2012; Scharek et al., 1999a, 1999b). The export of DDN may either be direct, through sinking of diazotrophs, or indirect, through the transfer of DDN to non-diazotrophic plankton in the photic zone, that is subsequently exported. While DDAs can directly contribute to particle export (Karl et al., 2012; Subramaniam et al., 2008; Yeung et al., 2012), the DDN export efficiency appears to depend on the diazotroph community composition present in surface waters.

The positive buoyancy of Trichodesmium spp. probably prevents its downward flux and settling in sediment traps (Capone et al., 1997; Walsby, 1992), although programmed cell death (PCD) causing bloom demise can cause rapid export of Trichodesmium biomass to depth (Bar-Zeev et al., 2013; Berman-Frank et al., 2004; Spungin et al., 2016). In the eastern tropical north Pacific, when the diazotrophic community was dominated by UCYN-A and Trichodesmium spp., $\mathrm{N}_{2}$ fixation contributed $\sim 10 \%$ of the export (White et al., 2012); when DDAs dominated the diazotrophic community they contributed $\sim 44 \%$ of export production, thereby suggesting that DDAs have a higher export efficiency compared to Trichodesmium spp. and UCYN-A. Despite their recent recognition as key oceanic diazotrophs (Luo et al., 2012), the export efficiency of UCYN from other lineages (UCYN$\mathrm{B}$ and $\mathrm{UCYN}-\mathrm{C}$ ) is currently undetermined as no published studies of natural UCYN-B and C blooms and their fate in the ocean are available to date.

The determination of direct vs. indirect export requires diazotroph quantification in both the water column and in sediment traps in addition to clarifying the actual transfer of DDN to the different groups of autotrophic and heterotrophic plankton. Few studies have thus focused on the direct coupling between $\mathrm{N}_{2}$ fixation and particulate export in general (see references above). Ideally such studies require the successful encounter of an oceanic diazotroph bloom, deployment of sediment traps and long-term (several weeks) monitoring of the biogeochemical characteristics of the water body influenced by the bloom, which are rarely accomplished. The patchy distribution of diazotrophs in the surface ocean (Bombar et al., 2015), the temporal lag between production and export, the hydrodynamic features that may decouple production in surface, and export below the photic zone (Buesseler et al., 2007) also make these studies very challenging.

\subsection{Scientific objectives of the VAHINE project}

The main scientific research priorities of the project were the following:

- to quantify the DDN that enters the planktonic food web,

- to investigate how the development of diazotrophs influences the subsequent diversity, gene expression and production of primary producers, heterotrophic bacterioplankton and subsequently zooplankton abundance; 

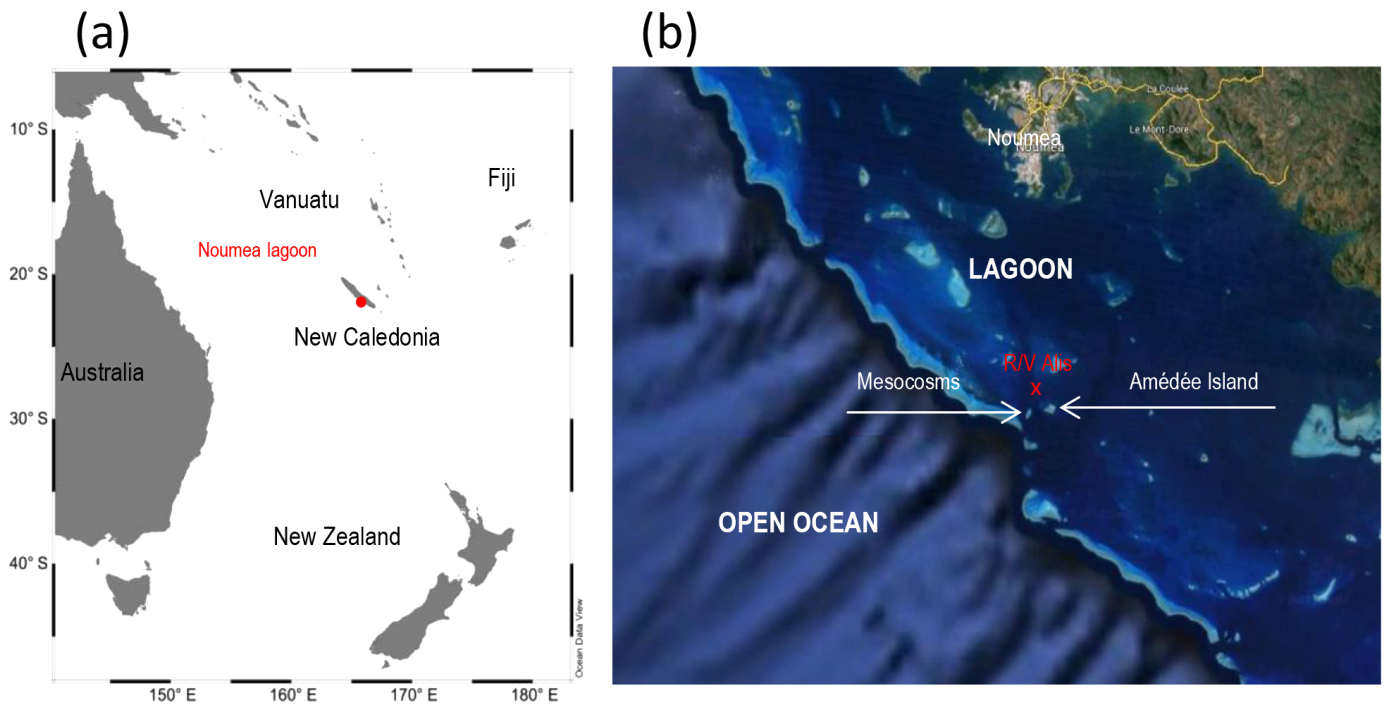

Figure 1. Study site of the VAHINE experiment. Location map of New Caledonia in the south-western Pacific (a), Map of the Noumea lagoon showing the location of mesocosms at the entrance of the lagoon, $28 \mathrm{~km}$ off the coast (b).

- to examine whether different functional types of diazotrophs significantly modify the stocks and fluxes of the major biogenic elements $(\mathrm{C}, \mathrm{N}, \mathrm{P})$;

- to elucidate whether the efficiency of particulate matter export depends on the development of different functional types of diazotrophs.

To achieve these goals and concurrently determine $\mathrm{N}_{2}$ fixation and particle export, we isolated large water masses containing ambient planktonic communities by deploying three large-volume $\left(\sim 50 \mathrm{~m}^{3}\right)$ mesocosms (Bonnet et al., 2016b) thereby maintaining a unique water-mass with minimal disturbance of the in situ light and temperature conditions (Guieu et al., 2014). The experimental location in the southwestern Pacific region was chosen as in this area some of the highest rates of oceanic $\mathrm{N}_{2}$ fixation occur (Bonnet et al., 2015; Messer et al., 2015). Additionally, to enhance $\mathrm{N}_{2}$ fixation, the mesocosms were intentionally fertilized with dissolved inorganic phosphorus (DIP). The experiment lasted 23 days and was characterized by a dominance of DDAs during the first half of the experiment (days 2-14) and a bloom of UCYN-C during the second half of the experiment (days 15-23), providing a unique opportunity to compare the DDN transfer and export efficiency associated with specific diazotrophs in this experimental system. Some additional process experiments performed on Trichodesmium spp. which bloomed outside the mesocosms on the last two days are also presented here.

Below, we summarize the scientific strategy used in this study, as well as some of the major results obtained during this project and propose some scientific perspectives for the future.

\section{Scientific strategy}

\subsection{Brief description of the mesocosms and study site}

The large-volume $\left(\sim 50 \mathrm{~m}^{3}\right)$ mesocosm experiment was undertaken in New Caledonia, located $1500 \mathrm{~km}$ east of Australia in the Coral Sea (south-western tropical Pacific, Fig. 1). Three replicate polyethylene and vinyl acetate mesocosms (diameter $2.3 \mathrm{~m}$, height $15 \mathrm{~m}$, volume $\sim 50 \mathrm{~m}^{3}$, Fig. 2) were deployed $28 \mathrm{~km}$ off the coast of New Caledonia at the entrance to the Noumea coral lagoon $\left(22^{\circ} 29.073 \mathrm{~S}\right.$ $166^{\circ} 26.905 \mathrm{E}$ ) for 23 days from 13 January to 6 February 2013 (austral summer). The New Caledonian lagoon was chosen as it is a well-studied environment (Special issue Marine Pollution Bulletin 2010; Grenz and LeBorgne, 2010) submitted to high oceanic influence (Ouillon et al., 2010) and exhibiting typical LNLC conditions during the summer season $\left(\mathrm{NO}_{3}^{-}\right.$concentrations $<0.04 \mu \mathrm{mol} \mathrm{L}^{-1}$ and chlorophyll $a$ (Chl $a) \sim 0.10-0.15 \mu \mathrm{g} \mathrm{L}^{-1}$ (Fichez et al., 2010). Primary productivity is N-limited throughout the year (Torréton et al., 2010), giving diazotrophs a competitive advantage. New Caledonian waters support high $\mathrm{N}_{2}$ fixation rates (151-703 $\mu \mathrm{mol} \mathrm{N} \mathrm{m}{ }^{-2} \mathrm{~d}^{-1}$; Garcia et al., 2007), as well as high Trichodesmium spp. (Dupouy et al., 2000; Rodier and Le Borgne, 2008, 2010) and UCYN abundances (Biegala and Raimbault, 2008), therefore representing an ideal location to implement the VAHINE project and study the fate of DDN in the marine ecosystem.

DIP availability can control $\mathrm{N}_{2}$ fixation in the southwestern Pacific (Moutin et al., 2005, 2008); hence the mesocosms were intentionally fertilized with $\sim 0.8 \mu \mathrm{M}$ DIP $\left(\mathrm{KH}_{2} \mathrm{PO}_{4}\right)$ on the evening of day 4 to alleviate any potential 
(a)

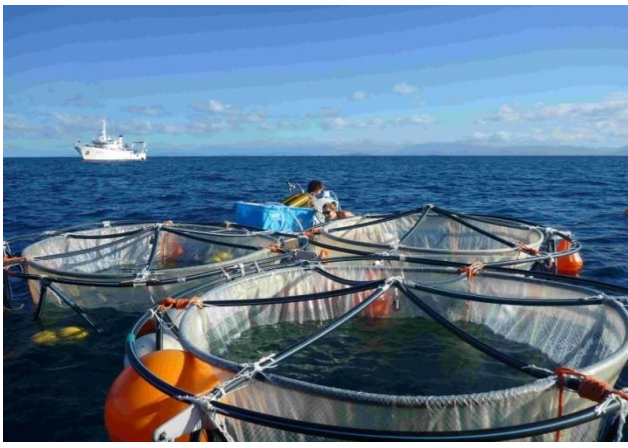

(b)

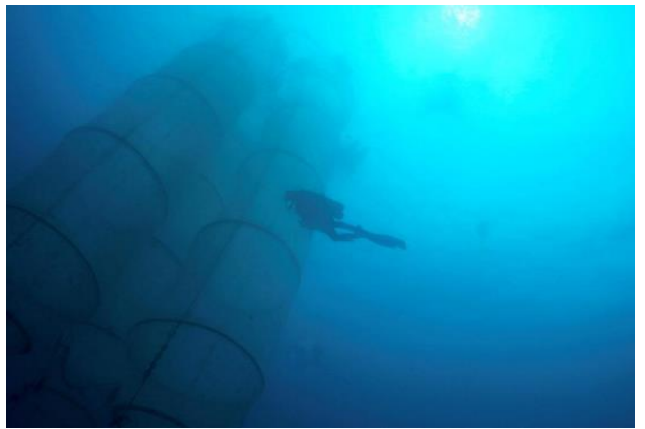

(c)

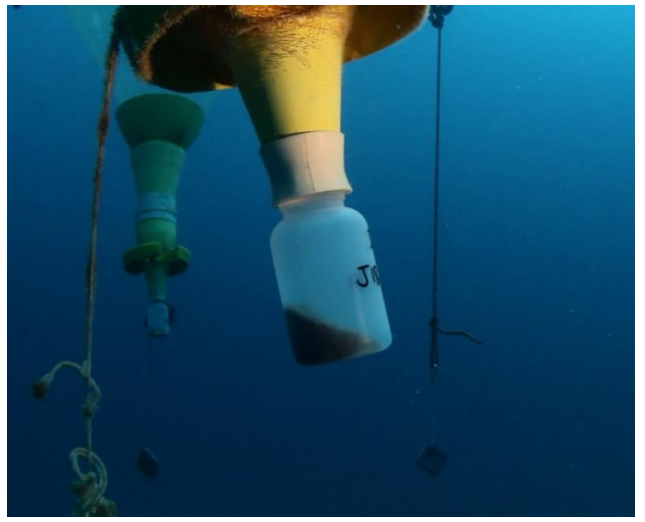

Figure 2. View of the mesocosms from above (a), from the seafloor (b) and view of the sediment traps that collect sinking particles (c). Photos credits: J. M. Boré and E. Folcher, IRD.

DIP limitation and promote $\mathrm{N}_{2}$ fixation and even diazotroph blooms for the purpose of the project.

The mesocosms used for this study are well suited for conducting replicated process studies on the first levels of the pelagic food web (Bonnet et al., 2016b; Guieu et al., 2010, 2014). They are equipped with sediment traps allowing the collection of sinking material. Due to the height of the mesocosms $(15 \mathrm{~m})$, they do not represent processes occurring in the full photic layer but allow studying the dynamics of $\mathrm{C}$, $\mathrm{N}, \mathrm{P}$ pools/fluxes and export associated with the plankton diversity in the same water mass, and comparing these dynamics both before and after the DIP fertilization, and under contrasted conditions regarding the diazotroph community composition (cf. below). Detailed surveys performed in LNLC environments revealed that temperature and light con- ditions are not affected by the presence of the mesocosms compared to surrounding waters (Bonnet et al., 2016b; Guieu et al., 2010, 2014). These studies also revealed a good replicability and low variability between stocks, fluxes and plankton diversity measurements among the replicate mesocosms. Hence, the discussion below will consider the average between the three mesocosms deployed in this study.

\subsection{Sampling strategy and logistics}

A complete description of the mesocosms design and deployment strategy is given in the introductory article (Bonnet et al., 2016b). In total, over 47 stocks, fluxes, enzymatic activities and diversity parameters were measured daily by the 40 scientists involved in the project. Protocols for each measured parameter are detailed in the specific contributions to this special issue and will not be described here. Modelling has also accompanied all steps of the project (see Gimenez et al., 2016 and Sect. 5 below).

Sampling for stocks, fluxes and plankton diversity measurements was performed daily at 07:00 LT (local time) in each of the three mesocosms (M1, M2 and M3) and in surrounding waters (hereafter called "lagoon waters") from day 2 (15 January, the day of the mesocosms closure) to day 23 (6 February) at three selected depths (1, 6 and $12 \mathrm{~m})$ to study the vertical variability within mesocosms and in lagoon waters. For flux measurements, bottles were incubated on an in situ mooring line at the appropriate sampling depth set up close to the mesocosms. Vertical CTD profiles were then performed daily at 10:00 LT in every mesocosm and in lagoon waters using a SBE 19 plus Seabird CTD to obtain the vertical profiles of temperature, salinity and fluorescence. Finally, sediment traps were collected daily by SCUBA divers at 10:30 LT; see details in Bonnet et al. (2016b).

\section{Evolution of the main standing stocks, fluxes and biological characteristics during the VAHINE experiment}

Initial hydrological and biogeochemical conditions (i.e. conditions in ambient waters the day of mesocosms deployment - 13 January, day 0) were typical of those encountered in the oligotrophic Noumea lagoon during austral summer conditions (Fichez et al., 2010; Le Borgne et al., 2010), with seawater temperature of $25.5^{\circ} \mathrm{C}$, surface salinity of $35.15, \mathrm{NO}_{3}^{-}$-depleted waters $\left(0.04 \pm 0.01 \mu \mathrm{mol} \mathrm{L}{ }^{-1}\right)$, low DIP concentrations $\left(0.04 \pm 0.01 \mu \mathrm{mol} \mathrm{L}^{-1}\right)$ and Chl $a$ concentrations of $0.20 \mu \mathrm{g} \mathrm{L}^{-1}$. $\mathrm{N}_{2}$ fixation rates were $8.70 \pm 1.70 \mathrm{nmol} \mathrm{N} \mathrm{L}^{-1} \mathrm{~d}^{-1}$ and the diazotroph community was dominated by DDAs (het- $13.1 \times 10^{4}$ nifH copies $\mathrm{L}^{-1}$ and het-2 $1.2 \times 10^{4}$ nifH copies $\mathrm{L}^{-1}$ ) as well as UCYN-A2 $\left(1.5 \times 10^{4}\right.$ nifH copies $\left.\mathrm{L}^{-1}\right)$ and UCYN-A1 $\left(5.6 \times 10^{3}\right.$ nifH copies $\mathrm{L}^{-1}$ ), which together accounted for $95 \%$ of the total 

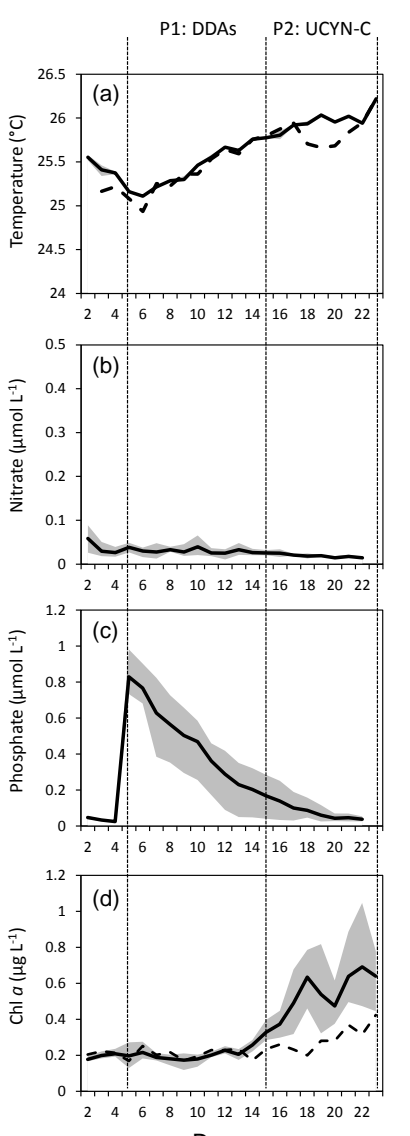

Day
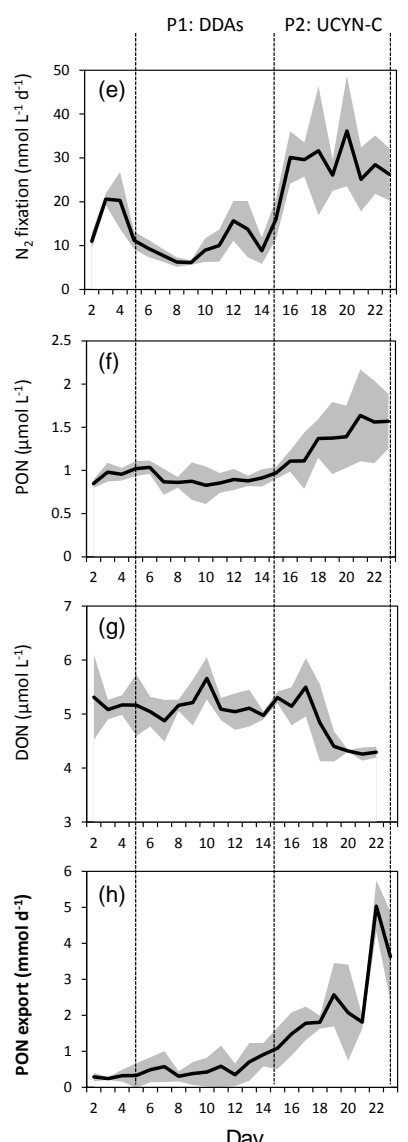

Day

Figure 3. Evolution of sea surface temperature $\left({ }^{\circ} \mathrm{C}\right.$; a $), \mathrm{NO}_{3}^{-}$ $\left(\mu \mathrm{molL} \mathrm{L}^{-1} ; \mathbf{b}\right), \mathrm{DIP}\left(\mu \mathrm{molL} \mathrm{L}^{-1} ; \mathbf{c}\right), \mathrm{Chl} a\left(\mu \mathrm{g} \mathrm{L}^{-1} ; \mathbf{d}\right), \mathrm{N}_{2}$ fixation rates $\left(\right.$ nmol N L $\left.{ }^{-1} \mathrm{~d}^{-1} ; \mathbf{e}\right)$, PON concentrations $\left(\mu \mathrm{mol} \mathrm{L}{ }^{-1} ; \mathbf{f}\right)$, DON concentrations $(\mu \mathrm{mol} \mathrm{L}-1 ; \mathbf{g})$ and PON export $\left(\mathrm{mmold}^{-1}\right.$; h) over the 23 days of the VAHINE mesocosm experiment. Lines represent the average of the three mesocosms and shaded areas represent the measured min and max values. Dashed lines represent the values represent the values in lagoon waters (outside the mesocosms)

nifH pool in the lagoon waters prior to the mesocosms closure (Turk-Kubo et al., 2015).

During the 23-day VAHINE mesocosm experiment, three major periods could be defined based on the main $\mathrm{C}, \mathrm{N}, \mathrm{P}$ stocks and fluxes (Berthelot et al., 2015b) and on the identity of the most abundant diazotrophs that developed in the mesocosms (Turk-Kubo et al., 2015): P0 from days 2 to 4 (i.e. prior to the DIP fertilization that occurred on the evening of day 4), P1 from days 5 to 14 and P2 from days 15 to 23 (Figs. 3 and 4). Figure 3 reports the main hydrological and biogeochemical parameters during the experiment. Figure 4 provides a synoptic view of the main changes (positive, negative, neutral) in the major stocks, fluxes and plankton community composition measured during $\mathrm{P} 1$ and $\mathrm{P} 2$, respectively.

Seawater temperature (Fig. 3) gradually increased both inside and outside the mesocosms over the 23 days of the experiment from 25.5 to $26.2^{\circ} \mathrm{C}$ on day 23 , which is the general trend observed during austral summer conditions (Le Borgne et al., 2010). The water column was well homogenized inside the mesocosms throughout the experiment (Bonnet et al., 2016b). $\mathrm{NO}_{3}^{-}$concentrations remained close to detection limit of conventional micromolar methods $\left(0.02 \mu \mathrm{mol} \mathrm{L}^{-1}\right)$ both inside and outside the mesocosms throughout the 23 days of the experiment (Fig. 3). The low $\left(0.04 \mu \mathrm{mol} \mathrm{L}^{-1}\right)$ DIP concentrations measured during P0 increased in the mesocosms right after the fertilization up to $\sim 0.8 \mu \mathrm{mol} \mathrm{L}{ }^{-1}$, then decreased quickly to reach values close to initial DIP concentrations $\left(\sim 0.04 \mu \mathrm{mol} \mathrm{L}^{-1}\right)$ at the end of the experiment.

A major objective of the experiment was to study the development of diazotroph blooms and the fate of DDN. Thus, our investigation of the biological response focused on diazotrophs and their subsequent influence on biological and biogeochemical signatures. $\mathrm{N}_{2}$ fixation rates tripled between $\mathrm{P} 1$ and $\mathrm{P} 2$, to reach extremely high rates during $\mathrm{P} 2\left(27.3 \pm 1.0 \mathrm{nmolN} \mathrm{L}^{-1} \mathrm{~d}^{-1}\right.$ on average and up to $70 \mathrm{nmolNL}^{-1} \mathrm{~d}^{-1}$; Bonnet et al., 2016a; Fig. 3), ranking among the highest rates reported in marine waters (Luo et al., 2012). DDAs dominated the diazotroph community composition during $\mathrm{P} 1$, and a bloom of UCYN-C occurred during P2 (Fig. 4). Standing stocks of Chl $a$ and particulate organic $\mathrm{N}$ (PON) increased, respectively, by a factor of 3 and 1.5 between P1 and P2 and subsequently, export of PON dramatically increased (by a factor of 5) in the mesocosms during P2 (Fig. 3). These results emphasize that the experimental mesocosm setup provided ideal conditions to study the fate of DDN associated with different diazotroph communities (DDAs vs. UCYN-C).

The synoptic view of the mesocosm dynamics (Fig. 4) indicates that after the DIP fertilization, DIP concentrations and DIP turn-over time increased significantly during P1, and alleviated P-limitation in the microbial communities as reflected in the significant decline in alkaline phosphatase activity (APA). The major biomass-indicative standing stock parameters (Chl $a$, PON, particulate organic C (POC) and $\mathrm{P}(\mathrm{POP})$ ) did not increase immediately after the DIP fertilization (P1) but during P2 (see below). Only PP increased significantly by a factor of 2 during P1, associated with a significant increase in $\mathrm{N}_{2}$-fixing DDAs and Prochlorococcus abundances. During P1, enhanced DIP availability enabled non-diazotrophic organisms with lower energetic requirements and higher growth rates such as Prochlorococcus to outcompete the diazotrophs in the mesocosms via utilization of recycled $\mathrm{N}$ derived from $\mathrm{N}_{2}$ fixation (Bonnet et al., 2016a). Thus, while PP increased, $\mathrm{N}_{2}$ fixation rates decreased significantly after the DIP spike.

During P2, diazotrophy was characterized by the significant increase in UCYN-C abundances that reached up to 


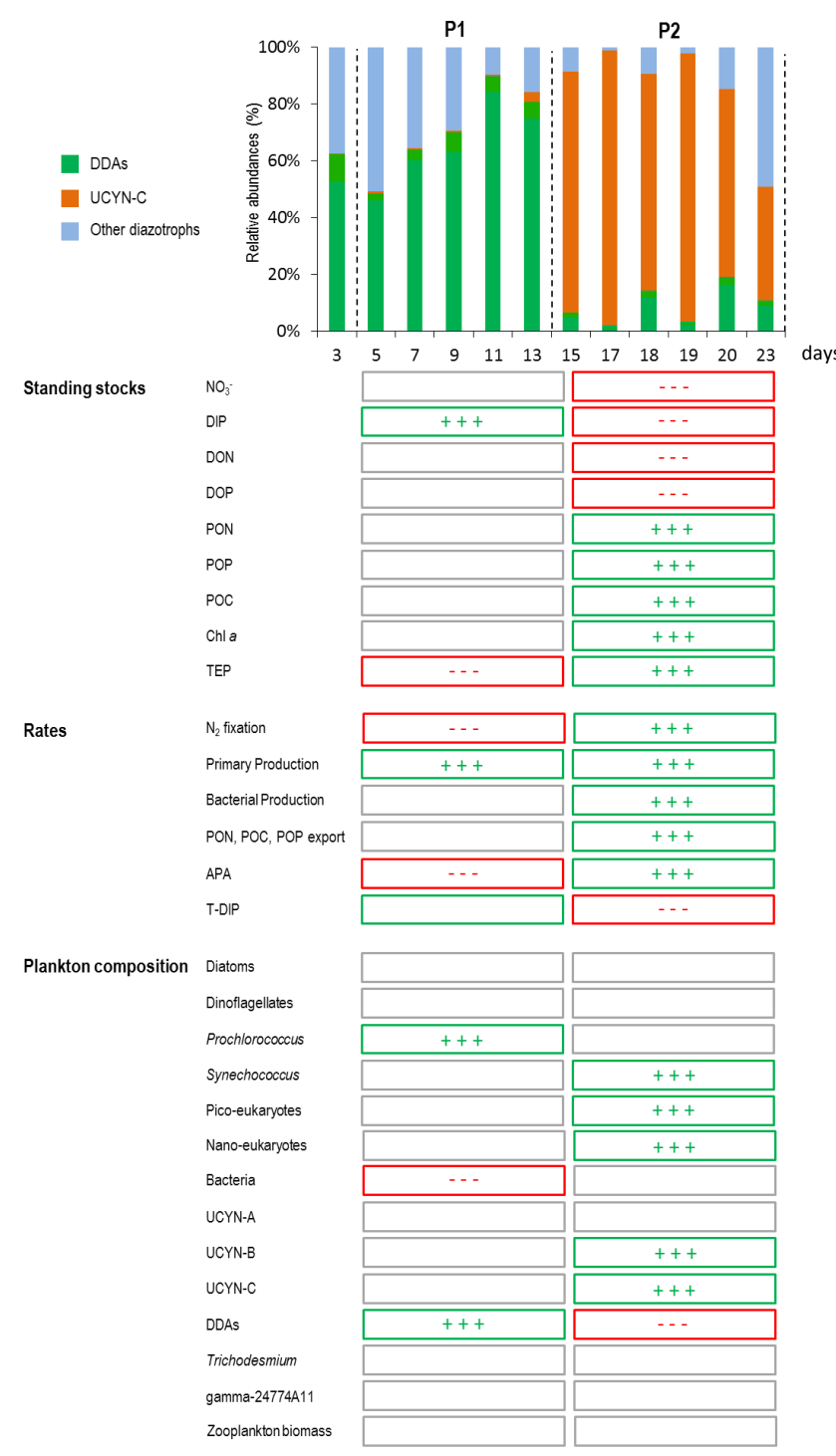

Figure 4. Upper panel: diazotroph community composition in the VAHINE mesocosm experiment during the experimental period. nifH-based abundances were summed for each sampling day to determine the percent contribution to the total diazotroph community from each major phylotype (data from Turk-Kubo et al., 2015). Bottom panel: simplified evolution of the major standing stocks, rates and plankton abundances measured during P1 (days 5 to 14) and P2 (days 15 to 23). Protocols for each parameter measurements are described in Berthelot et al. (2015b), Bonnet et al. (2016a, b), Van Wambeke et al. (2016), Berman-Frank et al. (2016), Leblanc et al. (2016), Turk-Kubo et al. (2015) and Hunt et al. (2016). Squares are represented in green when a significant $(p<0.05)$ increase was observed between each period (i.e. between P0 and P1 or between $\mathrm{P} 1$ and $\mathrm{P} 2$, Kruskall-Wallis test, $\alpha=0.05)$, in red when a significant $(p<0.05)$ decrease was observed and in grey when no significant change was observed between the different periods.
$7 \times 10^{5}$ nifH copies $\mathrm{L}^{-1}$, concomitant with the utilization of DIP and the significant decline in DIP concentrations, DIP turn-over time and a parallel increase of total APA. In all three mesocosms, the increase in UCYN-C abundances coincided with the day at which the DIP turnover time declined below $1 \mathrm{~d}$, indicative of DIP limitation (Berthelot et al., 2015b; Moutin et al., 2005). UCYN-C may have also utilized dissolved organic phosphorus (DOP) as a $\mathrm{P}$ source (Bandyopadhyay et al., 2011), driving the significant decline in DOP concentrations observed during P2 (Berthelot et al., 2015b, Fig. 4). The mesocosm approach also enabled the calculation of in situ growth rates for UCYN-C. These reached $\sim 2 \mathrm{~d}^{-1}$ during $\mathrm{P} 2$, i.e. higher than growth rates of any other diazotrophic phylotypes during P2 (Turk-Kubo et al., 2015), and indicating that, under $\mathrm{NO}_{3}^{-}$depletion and low DIP availability, UCYN-C was the most competitive diazotroph in the mesocosms.

Under the high $\mathrm{N}_{2}$ fixation conditions encountered during P2 (27.3 \pm 1.0 nmol N L $\left.{ }^{-1} \mathrm{~d}^{-1}\right)$, all standing stocks (Chl $a$, POC, PON, POP) increased in the mesocosms, together with $\mathrm{PP}$ and bacterial production (BP) (Fig. 4). The corresponding $\mathrm{NO}_{3}^{-}$, DIP, DON and DOP stocks for P2 decreased, indicating active consumption by the planktonic communities. As no external supply of $\mathrm{NO}_{3}$ was provided to the enclosed mesocosms, we calculated that the consumption of the $\mathrm{NO}_{3}^{-}$ stock initially present in the mesocosms $\left(0.04 \mu \mathrm{mol} \mathrm{L}^{-1}\right)$ represented less than $11 \%$ of the integrated $\mathrm{N}_{2}$ fixation rates. Therefore, $\mathrm{N}_{2}$ fixation supplied nearly all of the new production during the experiment. Our results demonstrate that in oligotrophic N-depleted systems, as long as DIP does not limit $\mathrm{N}_{2}$ fixation (Berthelot et al., 2015b), diazotrophs can provide enough new $\mathrm{N}$ to sustain high $\mathrm{PP}$ rates (exceeding $\left.2 \mu \mathrm{mol} \mathrm{C} \mathrm{L} \mathrm{C}^{-1} \mathrm{~d}^{-1}\right)$ and high biomass $\left(\sim 10 \mu \mathrm{mol} \mathrm{L}^{-1}\right.$ of POC and $0.7 \mu \mathrm{g} \mathrm{L}^{-1}$ of Chl $a$ ). Furthermore, during P2, DON provided an additional $\mathrm{N}$ source for non-diazotrophic phytoplankton and bacteria (Berthelot et al., 2015b).

Concurrent with the development of diazotrophic (UCYNC) populations, the abundance of Synechococcus, picoeukaryote, and nano-eukaryote primary producers also increased at the end of P2 (i.e. around day 16; Leblanc et al., 2016). The non-diazotrophic diatoms responded rapidly (i.e. around day 10-11) and increased to bloom values (100 000 cells $\mathrm{L}^{-1}$ ) simultaneously with the UCYN-C bloom on days 15-16 and prior to the increases in the pico- and nanophytoplankton (Pfreundt et al., 2016b; Van Wambeke et al., 2016). A drastic change in the diatom community structure paralleled the UCYN-C bloom with an almost monospecific bloom dominated by Cylindrotheca closterium. Despite the significant increase in BP during P2 and enrichments in the $16 \mathrm{~S}$ transcripts of specific bacterial groups (Pfreundt et al., 2016), the total abundance of heterotrophic bacteria did not change (Van Wambeke et al., 2016), probably due to grazing. Finally, no consistent temporal pattern in zooplankton biomass was detected over the course of the experiment 


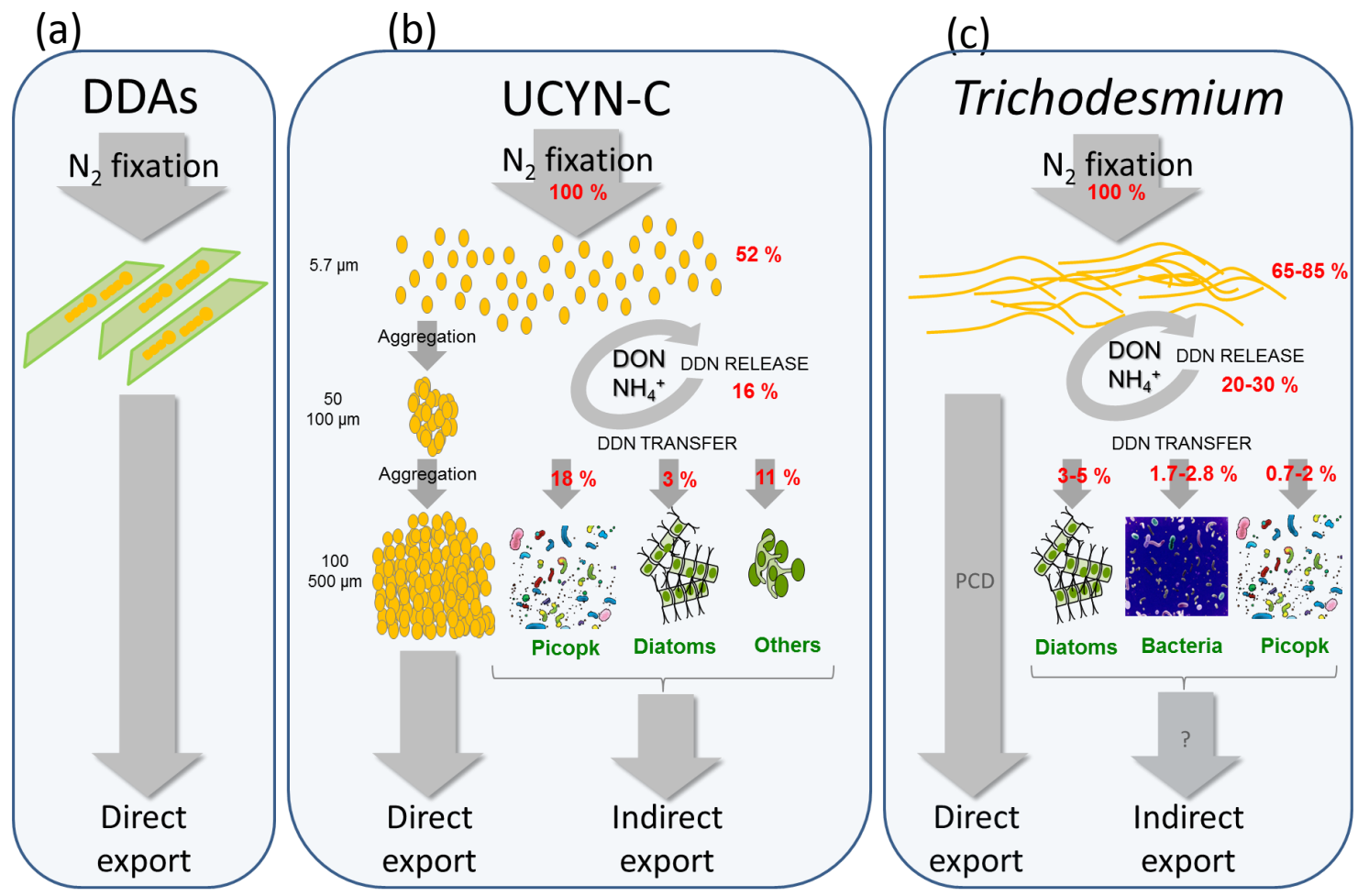

Figure 5. Summary of the simplified pathways of the potential DDN transfer in the first trophic level of the food web and potential of direct vs. indirect export of particulate matter for DDAs (a), UCYN-C (b) and Trichodesmium (c). DDN transfer data from (Bonnet et al., 2016a, c).

(Hunt et al., 2016), although changes were observed regarding the contribution of DDN to zooplankton biomass (see below).

\section{Tracking the fate of $\mathrm{N}_{2}$ fixation}

\subsection{Contribution of $\mathbf{N}_{2}$ fixation to export fluxes}

We specifically utilized the mesocosm approach to determine whether the composition of the diazotroph community influenced the subsequent export of particulate matter, and if so, how this was manifested. During P1, DDAs dominated the diazotroph community. For this time period, the biomass indices (Chl $a$, POC, PON, POP) were stable within the mesocosms (Figs. 3, 4), suggesting that the DDN associated with DDAs remained within the symbiotic associations (i.e. was poorly transferred to the rest of the planktonic community). Moreover, the amount of recently fixed $\mathrm{N}_{2}$ equaled that of exported PON, suggesting that the recently fixed $\mathrm{N}_{2}$ by DDAs was rapidly exported (Fig. 5a) as was also observed for DDAs in the tropical north Pacific at Station ALOHA (Karl et al., 2012). DDAs such as het-1 (Richelia in association with the diatom Rhizosolenia spp.), which dominated the DDA community during P1 in the mesocosms (Turk-Kubo et al., 2015) have indeed been shown to sink at high rates in the ocean (Scharek et al., 1999a).

During P2 and the UCYN-C bloom, the increases in Chl $a$, POC, PON and POP concentrations in the mesocosms suggest that a fraction of the recently produced biomass sustained by $\mathrm{N}_{2}$ fixation remained in the water column. The mesocosms enabled us to determine whether export associated with diazotrophs was direct (through the sinking of diazotrophic cells) or indirect (through the transfer of DDN to non-diazotrophic plankton that is subsequently exported). The direct export of UCYN has rarely been studied (White et al., 2012). Yet, UCYN contribution to vertical flux and export was assumed to be lower than the contribution of DDAs due to their small size (1 to $6 \mu \mathrm{m}$ ) and low sinking rates compared to DDAs (up to $500 \mu \mathrm{m}$ comprised of dense silica shells). qPCR quantification of diazotrophs in the sediment traps revealed that $\sim 10 \%$ of UCYN-C from the water column was exported to the traps daily, representing as much as $22.4 \pm 5.5 \%$ of the total POC exported at the height of the UCYN-C bloom (Bonnet et al., 2016a). Mechanistically, the vertical downward flux was enabled by the aggregation of the small $(5.7 \pm 0.8 \mu \mathrm{m})$ UCYN-C cells into large (100$500 \mu \mathrm{m})$ aggregates, the size of which increased with depth (Fig. 5b) possibly due to a sticky matrix composed also of transparent exopolymeric particles (TEPs). TEP concentrations increased during P2 (Fig. 4) providing both a nutrient 
source and aggregation enhancing substrate (Berman-Frank et al., 2016). These data, reported for the first time from the VAHINE experiment (Bonnet et al., 2016a), emphasize that despite their small size relative to DDAs, UCYN-C are able to directly export organic matter to depth, indicating that these small organisms should be considered in future biogeochemical studies.

The direct export of UCYN-C and other diazotrophs could not solely explain the very high exported matter observed during P2 (Bonnet et al., 2016a), suggesting another pathway of export during that period. An experiment performed during the UCYN-C bloom using nanoSIMS (nanoscale Secondary Ion Mass Spectroscopy) as described in Bonnet et al. (2016) demonstrated that a significant fraction of DDN $(21 \pm 4 \%)$ was quickly (within $24 \mathrm{~h}$ ) transferred to nondiazotrophic plankton, revealing that $\mathrm{N}_{2}$ fixation was fuelling non-diazotrophic plankton growth in the water column (Fig. 5b), suggesting an indirect export pathway in addition to the direct export of UCYN-C. The fact that UCYN-C fuelled non-diazotrophic plankton during P2 is consistent with the increase in biomass indicators as well as in non-diazotrophic phytoplankton abundances (diatom and picoplankton) simultaneously with or after the UCYNC bloom during P2.

The high export efficiency associated with the UCYN-C bloom compared to that associated with the DDAs during VAHINE was also indicated by $e$ ratio calculations $(e$ ratio $=$ POC export $/ \mathrm{PP}$ ), which quantify the efficiency of a system to export particulate $\mathrm{C}$ relative to the $\mathrm{C}$ fixed by $\mathrm{PP}$. During $\mathrm{P} 2$, the $e$ ratio was significantly $(p<0.05)$ higher (i.e. during the UCYN-C bloom; $39.7 \pm 24.9 \%$ ) than during P1 (i.e. when DDAs dominated the diazotrophic community; $23.9 \pm 20.2 \%$; Berthelot et al., 2015b). $\delta^{15} \mathrm{~N}$ measurements on DON, PON and particles from sediment traps further substantiated these results with a significantly $(p<0.05)$ higher contribution of $\mathrm{N}_{2}$ fixation to export production during P2 ( $56 \pm 24$ and up to $80 \%$ at the end of the experiment) compared to P1 (47 $\pm 6 \%$; Knapp et al., 2015). The contribution of $\mathrm{N}_{2}$ fixation to export (up to $80 \%$ ) was very high in our study compared with reports from other tropical and subtropical regions where active $\mathrm{N}_{2}$ fixation contribute 10 to $25 \%$ to export production (e.g. Altabet, 1988; Knapp et al., 2005). This is consistent with the extremely high $\mathrm{N}_{2}$ fixation rates measured in the mesocosms (up to 70 nmol N L ${ }^{-1} \mathrm{~d}^{-1}$ ) and compared with those measured from other regions (Luo et al., 2012).

Export associated with Trichodesmium spp. was not studied in the present mesocosm experiment as only limited numbers of Trichodesmium spp. were counted in the mesocosms (Turk-Kubo et al., 2015). Its potential for export is discussed below based on parallel studies from the region and intensive short-term experiments on surface blooms of Trichodesmium that appeared outside the mesocosms on days 22-23 (Spungin et al., 2016).

\subsection{DDN release and transfer to the food web}

\subsubsection{DDN release and transfer to non-diazotrophic phytoplankton and bacteria}

Within VAHINE we also assessed the quantity of DDN entering the planktonic food web as a function of the dominant diazotroph players, and examined which planktonic communities benefited the most from the DDN (i.e. small vs. large phytoplankton or microbial food web).

Diazotrophs transfer DDN to phytoplankton and heterotrophic prokaryotes via the dissolved $\mathrm{N}$ pool (DON and $\mathrm{NH}_{4}^{+}$). During the maximal abundance of UCYN-C, these were responsible for $90 \pm 29 \%$ of total $\mathrm{N}_{2}$ fixation rates in the mesocosms (Bonnet et al., 2016a). During this period, the DDN released to the dissolved pool accounted for $7.1 \pm 1.2$ to $20.6 \pm 8.1 \%$ of gross $\mathrm{N}_{2}$ fixation (Bonnet et al., 2016a; based on the direct measurement of the isotopic signature $\left({ }^{15} \mathrm{~N}\right)$ of the total dissolved $\mathrm{N}$ according to the denitrifying method; Knapp et al., 2005). This proportion is higher than that reported for UCYN-C in monospecific cultures using an equivalent method $\left(1.0 \pm 0.3\right.$ to $1.3 \pm 0.2 \%$ of gross $\mathrm{N}_{2}$ fixation (Benavides et al., 2013a; Berthelot et al., 2015a). At the same time as UCYN-C bloomed, the diverse diazotroph community present in the mesocosms (Turk-Kubo et al., 2015) also contributed to the DDN release. Additionally, exogenous factors such as viral lysis (Fuhrman, 1999) and sloppy feeding (O’Neil and Roman, 1992) occur in natural populations and could enhance $\mathrm{N}$ release compared to the mono-culture studies. Here, we demonstrate that natural UCYN blooms may result in substantial DDN release to the marine environment.

The physiological state of cells probably plays a critical role in the quantity and availability of DDN to the microbial communities as demonstrated in a study (applying identical methodology) from two naturally occurring blooms of Trichodesmium spp. in the same area (New Caledonian lagoon) (Bonnet et al., 2016c). DDN release from these blooms was slightly higher (bloom 1: $20 \pm 5$ to $48 \pm 5 \%$ and bloom 2: $13 \pm 2$ to $28 \pm 6 \%$ of gross $\mathrm{N}_{2}$ fixation) compared to UCYNC (Bonnet et al., 2016c). A decaying Trichodesmium spp. bloom (bloom 1) led to high DDN release rates and high $\mathrm{NH}_{4}^{+}$accumulation (up to $3.4 \mu \mathrm{mol} \mathrm{L}{ }^{-1}$ ) in the dissolved pool, while we did not observe this in exponentially growing Trichodesmium (bloom 2). The importance of physiological status rather than specific diazotroph types was further substantiated in earlier Trichodesmium culture studies (Mulholland et al., 2004; Mulholland and Capone, 2000) and similar DDN release between Trichodesmium spp. and three strains of UCYN-B and C were found by Berthelot et al. (2015a).

Previous comparisons between gross and net $\mathrm{N}_{2}$ fixation rates indicated high DDN release rates for oceanic populations of Trichodesmium spp. (40-50\% of gross $\mathrm{N}_{2}$ fixation on average, and up to $97 \%$, (Mulholland, 2007) and references therein). The physiological status of these popula- 
tions may have influenced the fluxes. Furthermore, the values could reflect a methodological overestimation due to the use of the ${ }^{15} \mathrm{~N}_{2}$ bubble method (Großkopf et al., 2012; Montoya et al., 1996) that may lead to greater differences between gross and net $\mathrm{N}_{2}$ fixation (see introduction). Currently, direct measurement of the ${ }^{15} \mathrm{~N}$ signature of the dissolved $\mathrm{N}$ pool itself (either the dissolved pool through the Knapp et al. (2005) method or both the $\mathrm{NH}_{4}^{+}$and the DON using the Slawyk and Raimbault (1995) method) appears the preferred method to accurately quantify the amount of DDN released by diazotrophs in the dissolved pool (Berthelot et al., 2015a).

Once released in the form of $\mathrm{NH}_{4}^{+}$and/or DON, DDN can be taken up by surrounding planktonic communities. Experimental evidence from nanoSIMS experiments during VAHINE indicate that $21 \pm 4 \%$ of the ${ }^{15} \mathrm{~N}_{2}$ fixed during the UCYN-C bloom was transferred to the non-diazotrophic plankton after $24 \mathrm{~h}$ of incubation (Bonnet et al., 2016a). Among these $21 \pm 4,18 \pm 3 \%$ was transferred to picoplankton (including both pico-phytoplankton and heterotrophic prokaryotes) and $3 \%$ to diatoms (Fig. 5b), suggesting that picoplankton would be more competitive than diatoms using DDN, which is consistent with the increase in Synechococcus and pico-eukaryote abundances by a factor of 2 following the UCYN-C bloom (Leblanc et al., 2016; Pfreundt et al., 2016b). The short-term nanoSIMS experiment was performed on day 17, when pico- and nanoplankton dominated the phytoplankonic biomass and diatom abundances declined probably due to DIP limitation (Leblanc et al., 2016). Picoplankton can efficiently utilize low DIP concentrations (Moutin et al., 2002) and/or can use alternative DOP sources (Benitez-Nelson and Buesseler, 1999). This may explain why picoplankton were the first beneficiaries of the DDN from UCYN-C specifically from days 17-23, although we cannot exclude that diatoms had also benefited from the DDN from UCYN-C earlier in the experiment (between days 10-11 and days 15-16 when they reached bloom values of $\sim 100000$ cells $L^{-1}$ ). A significant increase of both PP and BP during P2 (Fig. 2) suggests that both autotrophic and heterotrophic communities benefited from the DDN (Bonnet et al., 2016a). Calculations based on $\mathrm{C}: \mathrm{N}$ molar ratios show that $\mathrm{N}_{2}$ fixation may have provided $\sim 30 \%$ of the $\mathrm{N}$ demand of the $\mathrm{N}$-limited bacteria during $\mathrm{P} 2$ (compared to $\sim 20 \%$ during P1), the rest provided by detritus and DON (Van Wambeke et al., 2016), which concentrations decreased during the 23 days (Berthelot et al., 2015b). Throughout VAHINE, the biological system inside the mesocosms was mostly autotrophic with an upper error limit close to the metabolic balance between autotrophy and heterotrophy (Van Wambeke et al., 2016). The relationships between $\mathrm{BP}$ and $\mathrm{N}_{2}$ fixation rates were weak (during P2) or absent (during P1), yet tightly coupled between BP and Chl $a$ concentrations and between BP and PP. This suggests that $\mathrm{N}_{2}$ fixation stimulated autotrophic communities and these subsequently fuelled heterotrophic prokaryotes through the pro- duction and release of dissolved organic matter including $\mathrm{C}$ (DOC; Van Wambeke et al., 2016).

In a recent study performed at the VAHINE study site, Berthelot et al. (2016) compared the DDN transfer efficiency to several groups of non-diazotrophic plankton as a function of the diazotroph groups dominating the community (Trichodesmium spp. vs. UCYN-B vs. UCYN-C). Simulated blooms of Trichodesmium spp., UCYN-B and UCYN$\mathrm{C}$ grown in culture added to ambient lagoon communities reveal that the primary route of transfer of DDN towards non-diazotrophs is $\mathrm{NH}_{4}^{+}$, and DON mainly accumulates in the dissolved pool, whatever the diazotroph considered. In all cases, the presence of diazotrophs stimulated biomass production of non-diazotrophs, with heterotrophic prokaryotes the main DDN beneficiaries followed by diatoms and picophytoplankton. NanoSIMS analyses revealed that heterotrophic prokaryotes were highly ${ }^{15} \mathrm{~N}$-enriched, confirming they can directly benefit from the DDN (Berthelot et al., 2016). Further studies are needed to study the indirect stimulation of heterotrophic prokaryotes through the release of DOC by diazotrophs and non-diazotrophic phytoplankton that were stimulated by the DDN.

Similar experiments $\left({ }^{15} \mathrm{~N}_{2}\right.$ labelling, flow cytometry cell sorting and nanoSIMS) performed on three naturally occurring Trichodesmium spp. blooms in the south-western Pacific illustrated that DDN was predominantly transferred to diatoms (Bonnet et al., 2016c). These results indicate that the extensive oceanic blooms of Trichodesmium spp. can contribute to a large indirect downward flux of organic matter by promoting large cells (e.g., diatoms and dinoflagellates) characterized by efficient export rates (Nelson et al., 1995; Bonnet et al., 2016c; Devassy et al., 1979; Lenes et al., 2001).

Direct export flux of Trichodesmium spp. blooms may also occur in cases where rapid $(<2 \mathrm{~d})$ bloom mortality occurs via a programmed cell death (PCD; Berman-Frank et al., 2004, 2007). PCD in Trichodesmium spp. is characterized by the loss of buoyancy (collapse of gas vesicles) and increased production of TEPs and aggregation leading to enhanced and massive vertical flux (Bar-Zeev et al., 2013). A Trichodesmium spp. bloom that occurred outside the VAHINE mesocosms on days 23-24 displayed mechanistic features of PCD including mass mortality within $24 \mathrm{~h}$, loss of gas vesicles, and high production of TEPs (Spungin et al., 2016). While we could not directly quantify the export flux as no sediment traps were deployed in the lagoon water outside the mesocosms, the characteristics of the bloom, lack of grazer influence and the demise of biomass suggests this would lead to high rates of export (Spungin et al., 2016) as demonstrated in culture simulations (Bar-Zeev et al., 2013; Fig. 5c).

\subsubsection{DDN transfer to zooplankton}

DDN transfer to zooplankton may either be direct, through the ingestion of diazotrophs, or indirect, i.e. mediated through the release of dissolved DDN by diazotrophs taken 
up by heterotrophic and autotrophic plankton and subsequently grazed by zooplankton. During the VAHINE experiment, the percent contribution of DDN to zooplankton biomass averaged $30 \%$ (range $=15$ to $70 \%$; Hunt et al., 2016), which is in upper range of values reported from high $\mathrm{N}_{2}$ fixation areas such as the subtropical north Atlantic (Landrum et al., 2011; Mompean et al., 2013; Montoya et al., 2002a), the Baltic Sea (Sommer et al., 2006; Wannicke et al., 2013b) and the pelagic waters off the New Caledonian shelf (Hunt et al., 2015).

During VAHINE all four of the qPCR targeted diazotrophs (Trichodesmium spp., het-1, het-2, UCYN-C) were found in zooplankton guts indicating a direct grazing of these four phylotypes (Hunt et al., 2016). Overall, the most frequently detected targets were het-1 (during P1; 17 to 180 nifH copies copepod $^{-1}$ ) and UCYN-C (during P2; 7 to 50 nifH copies copepod $^{-1}$ ), i.e. the most abundant phylotypes encountered in the mesocosms during P1 and P2, respectively. However, Trichodesmium spp. and het- 2 were also detected at relatively high abundances in copepod guts $(\sim 280$ nifH copies copepod $^{-1}$ ) despite their low abundance in the mesocosms, suggesting selective feeding and a possible top down control through zooplankton grazing for these two phylotypes.

Direct and efficient zooplankton grazing on UCYN-C was further substantiated by targeted grazing experiments during VAHINE which consisted of ${ }^{15} \mathrm{~N}_{2}$-labelled bottle incubations of freshly collected zooplankton in the presence of natural phytoplankton assemblages. The ${ }^{15} \mathrm{~N}_{2}$ label was taken up by the diazotroph in the incubation bottles and used as a marker of zooplankton diazotroph ingestion and/or ingestion of non-diazotrophic plankton grown on DDN. Zooplankton were highly ${ }^{15} \mathrm{~N}$ enriched after $72 \mathrm{~h}$ of incubation during the UCYN-C bloom (P2), slightly enriched during P1 when DDAs dominated to diazotrophic community and not enriched at all when a Trichodesmium spp. bloom was encountered outside the mesocosms during P2 (Hunt et al., 2016). This was a surprising finding given that het- 1 , and to a lesser extent Trichodesmium spp., were detected in copepod guts, and would suggest that UCYN-C are much more efficiently transferred to zooplankton compared to DDAs and Trichodesmium spp. While we demonstrated direct grazing of zooplankton on Trichodesmium spp., DDAs and UCYN$\mathrm{C}$, further studies are required to quantify a more general contribution of direct and indirect transfer of DDN to zooplankton.

\section{Modelling as a tool to infer the fate of DDN and the role of $\mathrm{N}_{2}$ fixation on productivity, food web structure and $\mathrm{C}$ export}

Modelling has accompanied every stage of the VAHINE project. Mesocosm 1D-vertical simulations with the biogeochemical mechanistic Eco3M-MED model (Alekseenko et al., 2014), enriched with diazotrophs for the present study and embedded in the Eco3M modelling platform (Baklouti et al., 2006), were utilized prior to the in situ experiments to aid in the scientific design of the experiment and in understanding the need and the optimal timing of the DIP enrichment. The biogeochemical model was first assessed using in situ data from the mesocosms and then applied to study the fate of DDN in the ecosystem (Gimenez et al., 2016). Finally, one of the main strengths of the modelling tool lies in the opportunity that it offers to separate the different processes that are deeply interlinked. Here we employed this to infer the role of $\mathrm{N}_{2}$ fixation on productivity, food web structure and $\mathrm{C}$ export. The simulation of the mesocosm experiment (including DIP enrichment) reported in Gimenez et al. (2016), hereafter referred to as the "REF" simulation, and its main results relative to the fate of the DDN are summarized below.

At the end of the REF simulation (set at 25 days in the model), $33 \%$ of the DDN was found in the diazotrophs, $43 \%$ in the non-diazotroph organisms, $16 \%$ in the DON pool, $3 \%$ in the particulate detrital organic pool and $5 \%$ in the traps, indicating that $\mathrm{N}_{2}$ fixation efficiently benefited non-diazotrophic organisms and contributed to particle export. The model results substantiated the mass balance of $\mathrm{N}$ (Berthelot et al., 2015b) demonstrating that during the first 10 days of the experiment, planktonic organisms did not significantly benefit from the DDN and that DDN did not accumulate in the water column (was not transferred to nondiazotrophic plankton). After day 10, the DDN proportion increased in all the non-diazotrophic plankton groups and simultaneously decreased in the non-living pools, although DON concentrations lagged decreasing only from day 13 . This decrease in DDN proportion in the abiotic $\mathrm{N}$ pools is due both to the assimilation of mineral and organic nutrients by phytoplankton and heterotrophic prokaryotes, as well as to the sinking of the produced organic matter through aggregation processes.

The model results further showed that the fraction of DDN in the exported particulate matter increased from day 10 until the end of the simulation, consistent with the high $e$ ratio (Berthelot et al., 2015b) during P2 (see above) and with the $\delta^{15} \mathrm{~N}$-budget (Knapp et al., 2016), emphasizing the higher contribution of $\mathrm{N}_{2}$ fixation to export production during P2 compared to P1 (Gimenez et al., 2016).

In the model, diazotrophs were assumed to release equal amounts of $\mathrm{NH}_{4}^{+}$and DON at a rate which increases nonlinearly with the absolute and relative $\mathrm{N}$ contents of diazotrophs (Gimenez et al., 2016). During P1, DDN accumulated in the DON pool (nearly up to $40 \%$ of the DDN generated from the beginning of the experiment is found in DON on day 13), whereas the proportion of DDN associated with $\mathrm{NH}_{4}^{+}$decreased rapidly from day 5 as $\mathrm{NH}_{4}^{+}$was immediately used by heterotrophic bacteria and phytoplankton. The proportion of DDN associated with DON decreased later (i.e. during P2) when the inorganic $\mathrm{N}$ pool was depleted. The model results are consistent with the ${ }^{15} \mathrm{~N}$ measurements from the $\mathrm{NH}_{4}^{+}$and $\mathrm{DON}$ pools, indicating that $\mathrm{NH}_{4}^{+}$was preferen- 

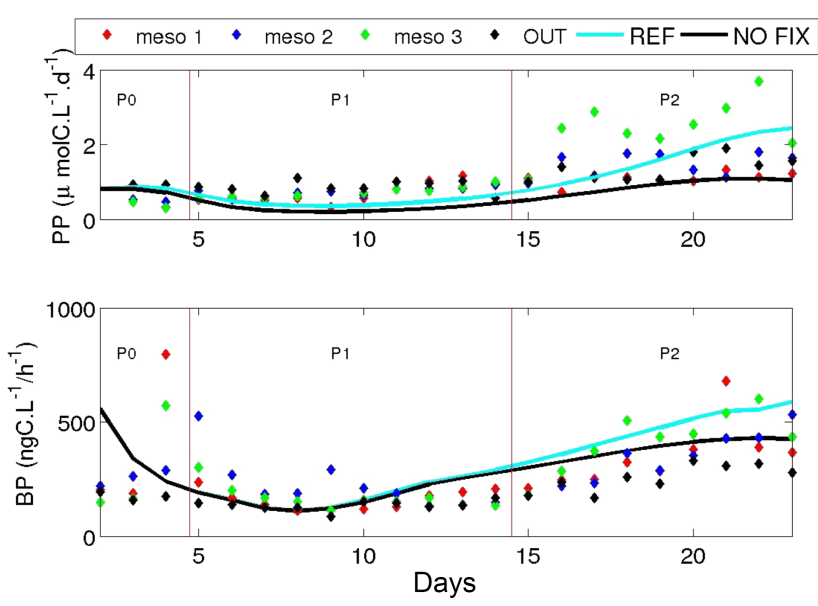

Figure 6. Evolution of PP $\left(\mu \mathrm{molCL} \mathrm{C}^{-1} \mathrm{~d}^{-1} ;\right.$ a) and bacterial production (ng C L ${ }^{-1} \mathrm{~h}^{-1}$ ) in the REF simulation (blue line) and the NOFIX simulation (black line; i.e. when the $\mathrm{N}_{2}$ fixation process is removed).

tially transferred to non-diazotrophic plankton compared to DON, which accumulated in the dissolved pool (Berthelot et al., 2016c).

The model results were further validated in the distribution of the DDN among the biotic compartments. Smallsize (pico- and nano-) phytoplankton, heterotrophic prokaryotes, heterotrophic nanoflagellates and ciliates were the main beneficiaries of DDN, as observed by the nanoSIMS studies (Berthelot et al., 2016a, c). Small-size phytoplankton and heterotrophic prokaryotes were indeed the main consumers of $\mathrm{NH}_{4}^{+}$and labile DON (the model excludes DON uptake by large-size phytoplankton), and heterotrophic nanoflagellates and ciliates respectively feed on heterotrophic prokaryotes and small-size phytoplankton. These results therefore indicate that DDN was transferred predominantly through pico-, nanophytoplankton and the microbial loop during the VAHINE experiment.

Both the in situ and modelling work summarized in the previous sections demonstrate the important contribution and role of the diazotrophic communities to PP (nondiazotrophic) and BP, to zooplankton feeding and eventually to $\mathrm{C}$ export.

To further assess the role of $\mathrm{N}_{2}$ fixation within the ecosystem, we used the REF simulation from Gimenez et al. (2016) and compared it to a new simulation in which we removed the $\mathrm{N}_{2}$ fixation capability of diazotrophs (hereafter named "NOFIX simulation"). The NOFIX simulation also included the following changes compared to the REF simulation to be consistent with the new environmental conditions: (i) the initial relative $\mathrm{N}$ quotas of diazotrophs have been set to $25 \%$ (instead of $100 \%$ in the reference simulation, i.e. same value as the one used for non-diazotrophs). To maintain an initial total $\mathrm{N}$ value identical to the one of the REF simulation, the remaining $\mathrm{N}$ content of diazotrophs has been allocated to the detrital N compartment; (ii) all along the NOFIX simulation, only the detrital particulate compartment is allowed to sink at a constant rate of $0.7 \mathrm{~m} \mathrm{~d}^{-1}$ (see Gimenez et al., 2016), whereas in the REF simulation, this was also the case only until day 10 beyond which all the compartments were allowed to sink at a rate increasing with time, in order to mimic the observed increase in the particulate sinking flux due to TEP release and aggregation .

When comparing the REF and NOFIX simulations (Fig. 6), we note that the shapes of the PP and BP curves remain the same, showing an increase in PP and BP during P2 in both simulations. However, in the NOFIX simulation, the magnitude of PP and BP is reduced by 2.5 and 1.5 -fold respectively. Furthermore, according to the model, $\mathrm{N}_{2}$ fixation fuelled $43.5 \%$ of PP and $8 \%$ of BP during the 23 days of the simulated experiment. This does not necessarily mean that non-diazotrophic autotrophs benefit more from the DDN compared to heterotrophs as the DDN was nearly equally distributed between autotrophs and heterotrophs (and slightly higher in heterotrophs; Gimenez et al., 2016). This higher effect on PP than on BP is derived from the fact that the diazotrophs themselves (and therefore a part of PP since only autotrophic diazotrophs were considered in the model) were strongly affected by their inability to fix $\mathrm{N}_{2}$ as suggested by the far lower abundance of UCYN-C in the NOFIX simulation compared to the REF one (Fig. 6). This also explains why removing $\mathrm{N}_{2}$ fixation first affected $\mathrm{PP}(\sim$ day 10$)$ and only later influenced $\mathrm{BP}(\sim$ day 15$)$.

We further assumed that, apart from diazotrophs, the organisms primarily influenced by the lack of $\mathrm{N}_{2}$ fixation (in the simulation) should be the organisms that benefited the most from the DDN (i.e. in which the highest percentages of DDN have been calculated by the model (see Fig. 6 in Gimenez et al., 2016). These organisms include small $(<10 \mu \mathrm{m})$ phytoplankton, heterotrophic prokaryotes, heterotrophic nanoflagellates and ciliates. Small phytoplankton and heterotrophic bacteria were indeed influenced (Fig. 7), and to a lesser extent and later heterotrophic nanoflagellates and ciliate abundance, but only until day 16 . After day 16 , ciliate abundance was slightly higher $(<5 \%$ between day 16 and 23) in the NOFIX simulation compared to the REF one, resulting predominantly from a top-down effect due to increased copepod predation in the NOFIX simulation from day 10 to day 23 (results not shown).

Our model did not include DDAs and did not allow the uptake of DON by large phytoplankton (i.e. diatoms). Thus, the DDN content in diatoms, and therefore in mesozooplankton, was probably slightly underestimated by the model in the REF simulation (Gimenez et al., 2016) compared to in situ data (Hunt et al., 2016). As a result, large phytoplankton and mesozooplankton abundances were nearly similar in the REF and NOFIX simulations (not shown). Hence, apart from ciliates (whose mortality also fuels the detrital particulate compartment as large phytoplankton and mesozooplankton), the organisms that mostly benefited from the DDN were 

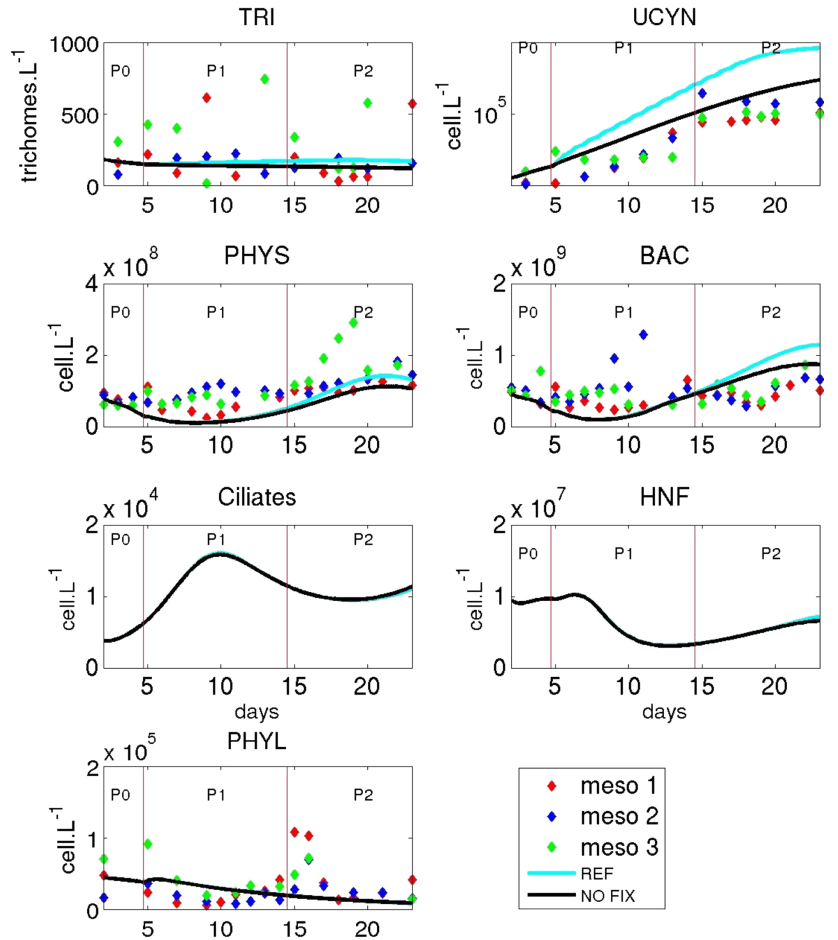

Figure 7. Evolution of plankton abundances (cells $\mathrm{L}^{-1}$ ) in the REF simulation (blue line) and the NOFIX simulation (black line; i.e. when the $\mathrm{N}_{2}$ fixation process is removed). TRI: Trichodesmium spp., UCYN: UCYN-C, BAC: heterotrophic bacteria, PHYS: small phytoplankton, HNF: heterotrophic nanoflagellates.

the small organisms, whose mortality fuels the dissolved organic pool.

How does $\mathrm{N}_{2}$ fixation impact $\mathrm{C}$ export? Absence of $\mathrm{N}_{2}$ fixation (NOFIX simulation) reduced export by $30 \%$ on day 23 compared to the REF simulation (Fig. 8). This difference in $\mathrm{C}$ export reaches $50 \%$ when the simulation duration is extended until day 35 (not shown). These results indicate that $\mathrm{N}_{2}$ fixation and the subsequent new production promotes $\mathrm{C}$ export to depth as the experimental VAHINE results demonstrated (Berthelot et al., 2015b; Knapp et al., 2015).

It is likely that during the experiment, TEP release favoured aggregation and accumulation of particles and subsequently enhanced vertical flux from the different compartments in the water column. To represent the latter phenomenon, we considered in the model that $10 \%$ of the living and non-living compartments were allowed to sink after day 10 (see Gimenez et al. (2016) for more details). Since this extra aggregation is mainly attributable to diazotrophs, it was not represented in the NOFIX simulation. However, we ran a third simulation (not shown) to further analyse the excess of $\mathrm{C}$ export in the REF simulation as compared to the NOFIX one (Fig. 8). This third simulation is intermediate between the REF and the NOFIX simulations in the sense that only the $\mathrm{N}_{2}$ fixation capability by diazotrophs is removed (but ag-

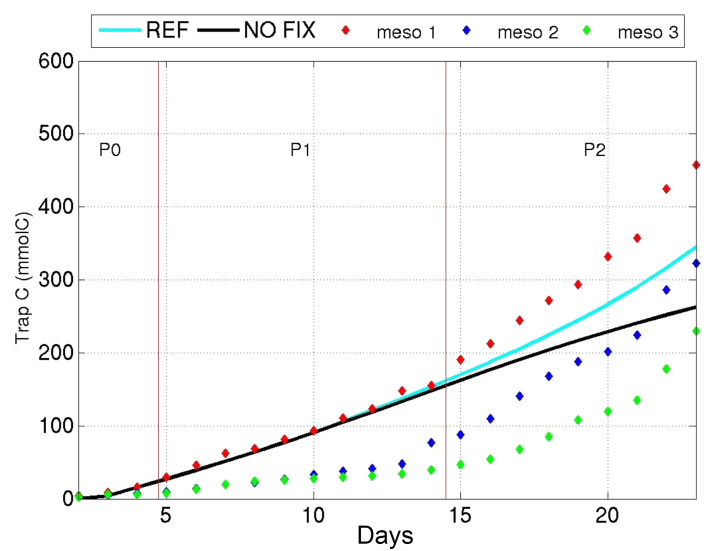

Figure 8. Evolution of $\mathrm{C}$ content collected in the mesocosm particle traps (mmol C) in the REF simulation (blue line) and the NOFIX simulation (black line; i.e. when the $\mathrm{N}_{2}$ fixation process is removed).

gregation processes are still represented). This simulation indicated that $\mathrm{C}$ export is nearly equal to that of the REF simulation after 25 days (they differ by only $2.9 \%$ ), thereby suggesting that during the 25 first days, the suppression of $\mathrm{N}_{2}$ fixation does not significantly impact carbon export fluxes. This further suggests that the higher $\mathrm{C}$ export in the REF simulation during P2 (Fig.8) is mainly due to aggregation processes mediated by diazotrophs-derived TEP release and the subsequent export of diazotrophs (Berman-Frank et al., 2016; Bonnet et al., 2015a). However, beyond day 25, the difference in $\mathrm{C}$ export between the REF and the third simulation increases up to $25 \%$ on day 35 . In other words, the $\mathrm{N}_{2}$ fixation process per se (by supporting PP and BP fluxes) contributes more and more to the enhanced $\mathrm{C}$ export as $\mathrm{N}_{2}$ fixation fluxes increase. Hence, on day $30, \mathrm{~N}_{2}$ fixation supports $\sim 50 \%$ of the excess $\mathrm{C}$ export observed between the REF and the NOFIX simulations, the remaining still being attributed to aggregation processes.

To conclude, $\mathrm{N}_{2}$ fixation has a significant impact on both direct and indirect $\mathrm{C}$ export via diazotroph fuelling of nondiazotrophic plankton as well as via aggregation processes. The model provides a lower limit of the major role played by $\mathrm{N}_{2}$ fixation on $\mathrm{C}$ export due to an underestimate of the DDN content in diatoms and in mesozooplankton. Finally, this study also points the need of further investigation on aggregation processes in relation with TEP release and its representation in models since its influence on $\mathrm{C}$ export may be of the same order of magnitude as the $\mathrm{N}_{2}$ fixation process per se.

\section{Conclusions and future work}

The VAHINE project provided unique opportunities to study and compare the fate of $\mathrm{N}_{2}$ fixation associated with different diazotrophs in the marine environment. The results 
showed that when the diazotroph community was dominated by DDAs, the DDN remained within the symbiotic associations, was poorly transferred to the non-diazotrophic phytoplankton and heterotrophic prokaryotes, yet could be transferred directly to zooplankton through grazing. The project results further substantiated previous data showing rapid export to depth of the recently fixed $\mathrm{N}_{2}$ by DDAs (Karl et al., 2012). An opportune bloom of UCYN-C during the VAHINE project demonstrated that when UCYN-C dominated the diazotroph community, $\sim 25 \%$ of the DDN was quickly ( $24 \mathrm{~h}$ ) transferred to the planktonic food web through the release of $\mathrm{DON}$ and $\mathrm{NH}_{4}^{+}$to the dissolved pool. These additional $\mathrm{N}$ sources were subsequently transferred to zooplankton, both directly (through the grazing of UCYN-C) and indirectly through the grazing of plankton grown on DDN from UCYN-C. Moreover, the VAHINE data explicitly revealed that when UCYN-C dominated the diazotroph community, the efficiency of the system to export POC relative to PP (e ratio) was higher than when DDAs dominated. This export is both direct, through the sinking of small $(5.7 \pm 0.8 \mu \mathrm{m})$ UCYN-C cells aggregated into large $(100-500 \mu \mathrm{m})$ particles having high sinking rates, and indirect, through the sinking of plankton benefitting from the enriched source of DDN. Future projects should extend the investigation of DDN export below the photic layer in the open ocean $(\sim 70-150 \mathrm{~m}$ in the oligotrophic ocean) to confirm the process study obtained during VAHINE in mesocosms in an experimental $15 \mathrm{~m}$-depth water column. In particular, are the aggregation processes of UCYN also observed in the open ocean? Although technically and logistically challenging, this feat may be accomplished through locating a research vessel in a 1D structure (cyclonic eddy harbouring high UCYN abundances for example) where horizontal advection is reduced and sediment traps are deployed to study the biological and biogeochemical characteristics of the photic zone for 1-2 weeks.

The VAHINE project also provided a unique opportunity to compare the transfer efficiency of DDN from UCYN and Trichodesmium spp. to the different compartments of the planktonic food web and revealed that the main beneficiaries of the DDN depend on both the physiological status (e.g. nutritionally balanced, stationary or decline phase) and the type of diazotroph. When Trichodesmium spp. bloom decay they release large amounts of $\mathrm{NH}_{4}^{+}$and mainly support diatom growth, indicating a large potential of indirect organic matter export during/after Trichodesmium spp. blooms. This is further substantiated by the study of PCD indicating a rapid direct export of Trichodesmium spp. itself, but further studies are needed in open ocean Trichodesmium spp. blooms to extrapolate our results to the field.

$\mathrm{NH}_{4}^{+}$appears to be the main form of DDN transferred to non-diazotrophic plankton. In future studies, chemical composition of DON released by different diazotrophs should be characterized to assess its lability as a function of the diazotrophs involved in $\mathrm{N}_{2}$ fixation and the stage of the bloom. It would also be informative to explore the amount and chem- ical composition of released DOC and better study the potential of diazotrophs to stimulate heterotrophs and their subsequent impact on the ocean metabolic balance.

Finally, in the future ocean, some diazotrophs such as Trichodesmium spp. (Hutchins et al., 2007; Levitan et al., 2007) and UCYN-B (Fu et al., 2008; no study is available on UCYN-C) may develop extensively under high temperature and $p \mathrm{CO}_{2}$ conditions (Dutkiewicz et al., 2015), while others such as UCYN-A would not be affected (Law et al., 2012). The results from the VAHINE project revealed that the diazotroph community composition can impact the planktonic food web structure and composition in the surface ocean and also affects the efficiency of particulate matter export to depth. Thus, current and predicted global changes require further knowledge and understanding of the fate and implications of changing scenarios of $\mathrm{N}_{2}$ fixation in the future oceans.

Acknowledgements. Funding for this research was provided by the Agence Nationale de la Recherche (ANR starting grant VAHINE ANR-13-JS06-0002), the INSU-LEFE-CYBER program, GOPS and IRD. The authors thank the captain and crew of the R/V Alis. We acknowledge the SEOH diver service from Noumea, as well as the technical service of the IRD research centre of Noumea for their helpful technical support together with C. Guieu, J.-M. Grisoni and F. Louis for the mesocosm design and the useful advice. Partial funding to Ilana Berman-Frank was provided through a collaborative grant with Sophie Bonnet from the Israel Ministry of Science and Technology (MOST) and the High Council for Science and Technology (HCST)-France, a German-Israeli Foundation for Scientific Research and Development (GIF) grant (no. 1133-13.8/2011), and a United States-Israel Binational Science Foundation (BSF) grant 15 (no. 2008048).

Edited by: D. G. Capone

\section{References}

Alekseenko, E., Raybaud, V., Espinasse, B., Carlotti, F., Queguiner, B., Thouvenin, B., Garreau, P., and Baklouti, M.: Seasonal dynamics and stoichiometry of the planktonic community in the NW Mediterranean Sea; a 3D modeling approach, Ocean Dynam., 64, 179-207, 2014.

Altabet, M. A.: Variations in Nitrogen Isotopic Composition between Sinking and Suspended Particles - Implications for Nitrogen Cycling and Particle Transformation in the Open Ocean, Deep-Sea Res., 35, 535-554, 1988.

Baklouti, M., Faure, V., Pawlowski, L., and Sciandra, A.: Investigation and sensitivity analysis 665 of a mechanistic phytoplankton model implemented in a new modular numerical tool (Eco3M) dedicated to biogeochemical modelling, Prog. Oceanogr., 71, 34-58, 2006.

Bandyopadhyay, A., Elvitigala, T., Welsh, E., Stöckel, J., Liberton, M., Min, H., Sherman, L. A., and Pakrasi, H. B.: Novel metabolic attributes of the genus cyanothece, comprising a group of unicellular nitrogen-fixing Cyanothece, MBio, 2, 2011. 
Bar-Zeev, E., Avishay, I., Bidle, K. D., and Berman-Frank, I.: Programmed cell death in the marine cyanobacterium Trichodesmium mediates carbon and nitrogen export, ISME J., 7, 2340-2348, 2013.

Benavides, M., Agawin, N., Arístegui, J., Peene, J., and Stal, L.: Dissolved organic nitrogen and carbon release by a marine unicellular diazotrophic cyanobacterium, Aquat. Microb. Ecol., 69, 69-80, 2013a.

Benavides, M., Bronk, D. A., Agawin, N. S. R., Pérez-Hernández, M. D., Hernández-Guerra, A., and Arístegui, J.: Longitudinal variability of size-fractionated $\mathrm{N}_{2}$ fixation and DON release rates along $24.5^{\circ} \mathrm{N}$ in the subtropical North Atlantic, J. Geophys. Res., 118, 3406-3415, 2013b.

Benitez-Nelson, C. R. and Buesseler, K. O.: Variability of inorganic and organic phosphorus turnover rates in the coastal ocean, Nature, 398, 502-505, 1999.

Berman-Frank, I., Bidle, K. D., Haramaty, L., and Falkowski, P. G.: The demise of the marine cyanobacterium, Trichodemsium spp., via an autocatalyzed cell death pathway, Limnol. Oceanogr., 49, 997-1005, 2004.

Berman-Frank, I., Rosenberg, G., Levitan, O., Haramaty, L., and X., M.: Coupling between autocatalytic cell death and transparent exopolymeric particle production in the marine cyanobacterium Trichodesmium, Enviro. Microbiol., 9, 1415-1422, 2007.

Berman-Frank, I., Spungin, D., Rahav, E., Van Wambeke, F., TurkKubo, K., and Moutin, T.: Dynamics of transparent exopolymer particles (TEP) during the VAHINE mesocosm experiment in the New Caledonian lagoon, Biogeosciences, 13, 3793-3805, doi:10.5194/bg-13-3793-2016, 2016.

Berthelot, H., Bonnet, S., Camps, M., Grosso, O., and Moutin, T.: Assessment of the dinitrogen released as ammonium and dissolved organic nitrogen by unicellular and filamentous marine diazotrophic cyanobacteria grown in culture, Front. Mar. Sci., 2, 80, doi:10.3389/fmars.2015.00080, 2015a.

Berthelot, H., Moutin, T., L'Helguen, S., Leblanc, K., Hélias, S., Grosso, O., Leblond, N., Charrière, B., and Bonnet, S.: Dinitrogen fixation and dissolved organic nitrogen fueled primary production and particulate export during the VAHINE mesocosm experiment (New Caledonia lagoon), Biogeosciences, 12, 40994112, doi:10.5194/bg-12-4099-2015, 2015 b.

Berthelot, H., Bonnet, S., Grosso, O., Cornet, V., and Barani, A.: Transfer of diazotroph-derived nitrogen towards nondiazotrophic planktonic communities: a comparative study between Trichodesmium erythraeum, Crocosphaera watsonii and Cyanothece sp., Biogeosciences, 13, 4005-4021, doi:10.5194/bg-13-4005-2016, 2016.

Biegala, I. C. and Raimbault, P.: High abundance of diazotrophic picocyanobacteria $(<3 \mu \mathrm{m})$ in a Southwest Pacific coral lagoon, Aquat. Microb. Ecol., 51, 45-53, 2008.

Bombar, D., Taylor, C. D., Wilson, S. T., Robidart, J. C., Rabines, A., Turk-Kubo, K. A., Kemp, J. N., Karl, D. M., and Zehr, J. P.: Measurements of nitrogen fixation in the oligotrophic North Pacific Subtropical Gyre using a free-drifting submersible incubation device, J. Plankton Res., 37, 727-739, 2015.

Bonnet, S., Biegala, I. C., Dutrieux, P., Slemons, L. O., and Capone, D. G.: Nitrogen fixation in the western equatorial Pacific: Rates, diazotrophic cyanobacterial size class distribution, and biogeochemical significance, Global Biogeochem. Cy., 23, 1-13, 2009.
Bonnet, S., Dekaezemacker, J., Turk-Kubo, K. A., Moutin, T., Hamersley, R. M., Grosso, O., Zehr, J. P., and Capone, D. G.: Aphotic $\mathrm{N}_{2}$ fixation in the Eastern Tropical South Pacific Ocean, PloS one, 8, e81265, doi:10.1371/journal.pone.0081265, 2013.

Bonnet, S., Rodier, M., Turk, K., K., Germineaud, C., Menkes, C., Ganachaud, A., Cravatte, S., Raimbault, P., Campbell, E., Quéroué, F., Sarthou, G., Desnues, A., Maes, C., and Eldin, G.: Contrasted geographical distribution of N2 fixation rates and nifH phylotypes in the Coral and Solomon Seas (South-Western Pacific) during austral winter conditions, Global Biogeochem. Cy., 29, doi:10.1002/2015GB005117, 2015.

Bonnet, S., Berthelot, H., Turk-Kubo, K., Fawcett, S., Rahav, E., L'Helguen, S., and Berman-Frank, I.: Dynamics of $\mathrm{N}_{2}$ fixation and fate of diazotroph-derived nitrogen in a low-nutrient, low-chlorophyll ecosystem: results from the VAHINE mesocosm experiment (New Caledonia), Biogeosciences, 13, 2653-2673, doi:10.5194/bg-13-2653-2016, 2016a.

Bonnet, S., Moutin, T., Rodier, M., Grisoni, J.-M., Louis, F., Folcher, E., Bourgeois, B., Boré, J.-M., and Renaud, A.: Introduction to the project VAHINE: VAriability of vertical and tropHIc transfer of diazotroph derived $\mathrm{N}$ in the south wEst Pacific, Biogeosciences, 13, 2803-2814, doi:10.5194/bg-13-28032016, 2016b.

Bonnet, S., Berthelot, H., Turk-Kubo, K., Cornet-Bartaux, V., Fawcett, S. E., Berman-Frank, I., Barani, A., Dekaezemacker, J., Benavides, M., Charriere, B., and Capone, D. G.: Diazotroph derived nitrogen supports diatoms growth in the South West Pacific: a quantitative study using nanoSIMS, Limnol. Oceanogr., doi:10.1002/lno.10300, 2016c.

Bronk, D. A., Sanderson, M. P., Mulholland, M. R., Heil, C. A., and O'Neil, J. M.: Organic and inorganic nitrogen uptake kinetics in field populations dominated by Karenia brevis, in: Harmful Algae, edited by: Steidinger, K. V. G. and Heil C. A., Florida Fish and Wildlife Conservation Commission, Florida Institute of Oceanography and Intergovernmental Oceanographic Commission of UNESCO, St. Petersburg, FL, 2004.

Bryceson, I. and Fay, P.: Nitrogen fixation in Oscillatoria (Trichodesmium) erythraea in relation to bundle formation and trichome differentiation, Mar. Biol., 61, 159-166, doi:10.1007/BF00386655, 1981.

Buesseler, K. O., Antia, A. N., Chen, M., Fowler, S. W., Gardner, W. D., Gustafsson, Ö., Harada, K., Michaels, A. F., V.D., R., Loeff, M., Sarin, M., Steinberg, D. K., and Trull, T.: An assessment of the use of sediment traps for estimating upper ocean particle fluxes, J. Mar. Res., 65, 345-416 2007.

Capone, D. G., Ferrier, M. D., and Carpenter, E. J.: Amino Acid Cycling in Colonies of the Planktonic Marine Cyanobacterium Trichodesmium thiebautii, Appl. Environ. Microbiol., 60, 39893995, 1994.

Capone, D. G., Zehr, J. P., Paerl, H. W., Bergman, B., and Carpenter, E. J.: Trichodesmium, a globally significant marine cyanobacterium, Science, 276, 1221-1229, 1997.

Chen, Y. L., Tuo, S., and Chen, H. Y.: Co-occurrence and transfer of fixed nitrogen from Trichodesmium spp. to diatoms in the lowlatitude Kuroshio Current in the North West Pacific, Mar. Ecol.Prog. Ser., 421, 25-38, 2011.

Devassy, V. P., Bhattathiri, P. M. A., and Qasim, S. Z.: Trichodesmium phenomenon, Indian J. Mar. Sci., 7, 168-186, 1978. 
Devassy, V. P., Bhattathiri, P. M. A., and Qasim, S. Z.: Succession of organisms following Trichodesmium phenomenon, Indian J. Mar. Sci., 8, 89-93, 1979.

Dupouy, C., Neveux, J., Subramaniam, A., Mulholland, M. R., Montoya, J. P., Campbell, L., Carpenter, E. J., and Capone, D. G.: Satellite captures trichodesmium blooms in the southwestern tropical Pacific, EOS, 81, 13-16, 2000.

Dutkiewicz, S., Morris, J. J., Follows, M. J., Scott, J., Levitan, O., Dyhrman, S. T., and Berman-Frank, I.: Impact of ocean acidification on the structure of future phytoplankton communities, Nature Climate Change, 5, 1002-1006, 2015.

Farnelid, H. and Riemann, L.: Heterotrophic $\mathrm{N}_{2}$-fixing bacteria: overlooked in the marine nitrogen cycle?, in: Nitrogen Fixation Research Progress, Nova Science Publishers, New York, 2008.

Farnelid, H., Andersson, A. F., Bertilsson, S., Al-Soud, W. A., Hansen, L. H., Sørensen, S., Steward, G. F., Hagström, A., and Riemann, L.: Nitrogenase gene amplicons from global marine surface waters are dominated by genes of non-cyanobacteria, PloS one, 6, e19223, doi:10.1371/journal.pone.0019223, 2011.

Fichez, R., Chifflet, S., Douillet, P., Gérard, P., Gutierrez, F., Jouon, A., Ouillon, S., and Grenz, C.: Biogeochemical typology and temporal variability of lagoon waters in a coral reef ecosystem subject to terrigeneous and anthropogenic inputs (New Caledonia), Mar. Pollut. Bull., 61, 309-322, 2010.

Foster, R. A. and O'Mullan, G. D.: Nitrogen-Fixing and Nitrifying Symbioses in the Marine Environment, in: Nitrogen in the Marine Environment, edited by: Capone, D. G., Bronk, D. A., Mulholland, M., and Carpenter, E. J., Elsevier Science, 2008.

Fu, F. X., Mulholland, M. R., N., G., Beck, A., Bernhardt, P., Warner, M., Sañudo-Wilhelmy, S., and Hutchins, D. A.: Interactions between changing $p \mathrm{CO}_{2}, \mathrm{~N}_{2}$ fixation, and Fe limitation in the marine unicellular cyanobacterium Crocosphaera, Limnol. Oceanogr., 53, 2472-2484, doi:10.4319/lo.2008.53.6.2472, 2008

Fuhrman, J. A.: Marine viruses and their biogeochemical and ecological effects, Nature, 399, 541-548, doi:10.1038/21119, 1999.

Furnas, M. J. and Mitchell, A. W.: Pelagic primary production in the Coral and southern Solomon Seas, Mar. Freshwater Res., 47, 395-705, 1996.

Garcia, N., Raimbault, P., and Sandroni, V.: Seasonal nitrogen fixation and primary production in the Southwest Pacific: nanoplankton diazotrophy and transfer of nitrogen to picoplankton organisms, Mar. Ecol.-Prog. Ser., 343, 25-33, 2007.

Gimenez, A., Baklouti, M., Bonnet, S., and Moutin, T.: Biogeochemical fluxes and fate of diazotroph derived nitrogen in the food web after a phosphate enrichment: Modeling of the VAHINE mesocosms experiment, Biogeosciences Discuss., doi:10.5194/bg-2015-611, in review, 2016.

Glibert, P. M. and Bronk, D.: Release of dissolved organic nitrogen by marine diazotrophic cyanobacteria, Trichodesmium spp., Appl. Environ. Microbiol., 60, 3996-4000, 1994.

Glibert, P. M. and O'Neil, J. M.: Dissolved organic nitrogen release and amino-acid oxidase activity by Trichodesmium, in: Marine cyanobacteria, ORSTOM, Bulletin de l'Institut Océanographoque, edited by: Charpy, L. and Larkum, T., Paris, 1999.

Grenz, C. and LeBorgne, R.: New Caledonia tropical lagoons: an overview of multidisciplinary investigations, Mar. Pollut. Bull., 61, 67-268, doi:10.1016/j.marpolbul.2010.06.030, 2010.
Großkopf, T., Mohr, W., Baustian, T., Schunck, H., Gill, D., Kuypers, M. M. M., Lavik, G., Schmitz, R. A., Wallace, G. W. R., and LaRoche, J.: Doubling of marine dinitrogen-fixation rates based on direct measurements, Nature, 488, 361-363, 2012.

Gruber, N.: The dynamics of the marine nitrogen cycle and its influence on atmospheric $\mathrm{CO}_{2}$, in: The ocean carbon cycle and climate, edited by: Follows, M. and Oguz, T., Kluwer Academic, Dordrecht, 2004.

Guieu, C., Dulac, F., Desboeufs, K., Wagener, T., Pulido-Villena, E., Grisoni, J.-M., Louis, F., Ridame, C., Blain, S., Brunet, C., Bon Nguyen, E., Tran, S., Labiadh, M., and Dominici, J.-M.: Large clean mesocosms and simulated dust deposition: a new methodology to investigate responses of marine oligotrophic ecosystems to atmospheric inputs, Biogeosciences, 7, 27652784, doi:10.5194/bg-7-2765-2010, 2010.

Guieu, C., Dulac, F., Ridame, C., and Pondaven, P.: Introduction to project DUNE, a DUst experiment in a low Nutrient, low chlorophyll Ecosystem, Biogeosciences, 11, 425-442, doi:10.5194/bg11-425-2014, 2014

Hunt, B. P. V., Allain, V., Menkes, C., Lorrain, A., Graham, B., Rodier, M., Pagano, M., and Carlotti, F.: A coupled stable isotope-size spectrum approach to understanding pelagic foodweb dynamics: A case study from the southwest sub-tropical Pacific, Deep-Sea Res. Pt. II, 113, 208-224, 2015.

Hunt, B. P. V., Bonnet, S., Berthelot, H., Conroy, B. J., Foster, R. A., and Pagano, M.: Contribution and pathways of diazotrophderived nitrogen to zooplankton during the VAHINE mesocosm experiment in the oligotrophic New Caledonia lagoon, Biogeosciences, 13, 3131-3145, doi:10.5194/bg-13-3131-2016, 2016.

Hutchins, D. A., Fu, F. X., Zhang, Y., Warner, M. E., Feng, Y., Portune, K., Bernhardt, P. W., and Mulholland, M. R.: $\mathrm{CO}_{2}$ control of Trichodesmium $\mathrm{N}_{2}$ fixation, photosynthesis, growth rates, and elemental ratios: Implications for past, present, and future ocean biogeochemistry, Limnol. Oceanogr., 52, 1293-1304, 2007.

Karl, D., Michaels, A., Bergman, B., Capone, D. G., Carpenter, E. J., and Letelier, R.: Dinitrogen fixation in the world's oceans, Biogeochemistry, 57/58, 47-98, 2002.

Karl, D. M., Letelier, R., Hebel, D. V., Bird, D. F., and Winn, C. D.: Trichodesmium blooms and new nitrogen in the North Pacific Gyre, Kluwer Academic Publishers, Dordrecht, 1992.

Karl, D. M., Letelier, R., Tupas, L., Dore, J., Christian, J., and Hebel, D.: The role of nitrogen fixation in biogeochemical cycling in the subtropical North Pacific Ocean, Nature, 388, 533538, 1997a.

Karl, D. M., Letelier, R. M., Tupas, R., Dore, J., Christian, J., and Hebel, D. V.: The role of nitrogen fixation in biogeochemical cycling in the subtropical North Pacific Ocean, Nature, 388, 533 538, 1997b.

Karl, D. M., Church, M. J., Dore, J. E., Letelier, R., and Mahaffey, C.: Predictable and efficient carbon sequestration in the North Pacific Ocean supported by symbiotic nitrogen fixation, P. Natl. Acad. Sci. USA, 109, 1842-1849, 2012.

Kerbrat, A. S., Darius, H. T., Pauillac, S., Chinain, M., and Laurent, D.: Detection of ciguatoxin-like and paralysing toxins in Trichodesmium spp. from New Caledonia lagoon, Mar. Pollut. Bull., 61, 360-366, 2010.

Knapp, A. N., Sigman, D. M., and Lipschultz, F.: N isotopic composition of dissolved organic nitrogen and nitrate at the Bermuda 
Atlantic Time-series Study site, Global Biogeochem. Cy., 19, 115, 2005.

Knapp, A. N., Fawcett, S. E., Martínez-Garcia, A., Leblond, N., Moutin, T., and Bonnet, S.: Nitrogen isotopic evidence for a shift from nitrate- to diazotroph-fueled export production in VAHINE mesocosm experiments, Biogeosciences Discuss., 12, 1990119939, doi:10.5194/bgd-12-19901-2015, 2015.

Konno, U., Tsunogai, U., Komatsu, D. D., Daita, S., Nakagawa, F., Tsuda, A., Matsui, T., Eum, Y.-J., and Suzuki, K.: Determination of total $\mathrm{N}_{2}$ fixation rates in the ocean taking into account both the particulate and filtrate fractions, Biogeosciences, 7, 2369-2377, doi:10.5194/bg-7-2369-2010, 2010.

Landrum, J. P., Altabet, M. A., and Montoya, J. P.: Basin-scale distributions of stable nitrogen isotopes in the subtropical North Atlantic Ocean: Contribution of diazotroph nitrogen to particulate organic matter and mesozooplankton, Deep-Sea Res. Pt. I, 58, 615-625, 2011

Law, C. S., Breitbarth, E., Hoffmann, L. J., McGraw, C. M., Langlois, R. J., LaRoche, J., Marriner, A., and Safi, K. A.: No stimulation of nitrogen fixation by non-filamentous diazotrophs under elevated $\mathrm{CO}_{2}$ in the South Pacific, Glob. Change Biol., 18, 3004 3014, 2012.

Le Borgne, R., Douillet, P., Fichez, R., and Torréton, J. P.: Hydrography and plankton temporal variabilities at different time scales in the southwest lagoon of New Caledonia: A review, Mar. Pollut. Bull., 61, 297-308, 2010.

Leblanc, K., Cornet, V., Caffin, M., Rodier, M., Desnues, A., Berthelot, H., Turk-Kubo, K., and Heliou, J.: Phytoplankton community structure in the VAHINE MESOCOSM experiment, Biogeosciences Discuss., doi:10.5194/bg-2015-605, in review, 2016.

Lenes, J. M. and Heil, C. A.: A historical analysis of the potential nutrient supply from the $\mathrm{N}_{2}$ fixing marine cyanobacterium Trichodesmium spp. to Karenia brevis blooms in the eastern Gulf of Mexico, J. Plankton Res., 32, 1421-1431, 2010.

Lenes, J. M., Darrow, B. P., Catrall, C., Heil, C. A., Callahan, L., Vargo, G. A., Byrne, R. H., Prospero, J. M., Bates, D. E., Fanning, K. A., and Walsh, J. J.: Iron fertilization and the Trichodesmium response on the West Florida shelf, Limnol. Oceanogr., 46, 1261-1277, 2001.

Levitan, O., Rosenberg, G., Šetlík, I., Šetlíkova, E., Gtigel, J., Klepetar, J., Prášil, O., and Berman-Frank, I.: Elevated $\mathrm{CO}_{2}$ enhances nitrogen fixation and growth in the marine cyanobacterium Trichodesmium, Glob. Change Biol., 13, 1-8, 2007.

Luo, Y.-W., Doney, S. C., Anderson, L. A., Benavides, M., BermanFrank, I., Bode, A., Bonnet, S., Boström, K. H., Böttjer, D., Capone, D. G., Carpenter, E. J., Chen, Y. L., Church, M. J., Dore, J. E., Falcón, L. I., Fernández, A., Foster, R. A., Furuya, K., Gómez, F., Gundersen, K., Hynes, A. M., Karl, D. M., Kitajima, S., Langlois, R. J., LaRoche, J., Letelier, R. M., Marañón, E., McGillicuddy Jr., D. J., Moisander, P. H., Moore, C. M., Mouriño-Carballido, B., Mulholland, M. R., Needoba, J. A., Orcutt, K. M., Poulton, A. J., Rahav, E., Raimbault, P., Rees, A. P., Riemann, L., Shiozaki, T., Subramaniam, A., Tyrrell, T., TurkKubo, K. A., Varela, M., Villareal, T. A., Webb, E. A., White, A. E., Wu, J., and Zehr, J. P.: Database of diazotrophs in global ocean: abundance, biomass and nitrogen fixation rates, Earth Syst. Sci. Data, 4, 47-73, doi:10.5194/essd-4-47-2012, 2012.

Mahaffey, C., Michaels, A. F., and Capone, D. G.: The conundrum of marine $\mathrm{N}_{2}$ fixation, Am. J. Sci., 305, 546-595, 2005.
Meador, T. B., Aluwihare, L. I., and Mahaffey, C.: Isotopic heterogeneity and cycling of organic nitrogen in the oligotrophic ocean, Limnol. Oceanogr., 52, 934-947, 2007.

Messer, L. F., Mahaffey, C., M Robinson, C., Jeffries, T. C., Baker, K. G., Bibiloni Isaksson, J., Ostrowski, M., Doblin, M. A., Brown, M. V., and Seymour, J. R.: High levels of heterogeneity in diazotroph diversity and activity within a putative hotspot for marine nitrogen fixation, ISME J., 10, 1499-1513, doi:10.1038/ismej.2015.205, 2015.

Mohr, W., Grosskopf, T., Wallace, D. R. W., and LaRoche, J.: Methodological underestimation of oceanic nitrogen fixation rates, PloS one, 9, 1-7, 2010.

Moisander, A. M., Serros, T., Pearl, R. W., Beinart, A., and Zehr, J. P.: Gammaproteobacterial diazotrophs and nifH gene expression in surface waters of the South Pacific Ocean, ISME J., 8, 19621973, doi:10.1038/ismej.2014.49, 2014.

Moisander, P. H., Beinart, R. A., Hewson, I., White, A. E., Johnson, K. S., Carlson, C. A., Montoya, J. P., and Zehr, J. P.: Unicellular Cyanobacterial Distributions Broaden the Oceanic $\mathrm{N}^{2}$ Fixation Domain, Science, 327, 1512-1514, 2010.

Mompean, C., Bode, A., Benitez-Barrios, V. M., Dominguez-Yanes, J. F., Escanez, J., and Fraile-Nuez, E.: Spatial patterns of plankton biomass and stable isotopes reflect the influence of the nitrogen-fixer Trichodesmium along the subtropical North Atlantic, J. Plankton Res., 35, 513-525, 2013.

Montoya, J. P., Voss, M., Kahler, P., and Capone, D. G.: A simple, high-precision, high-sensitivity tracer assay for $\mathrm{N}_{2}$ fixation, Appl. Environ. Microbiol., 62, 986-993, 1996.

Montoya, J. P., Carpenter, E. J., and Capone, D. G.: Nitrogen fixation and nitrogen isotope abundances in zooplankton of the oligotrophic North Atlantic, Limnol. Oceanogr., 47, 1617-1628, 2002a.

Montoya, J. P., Carpenter, E. J., and Capone, D. G.: Nitrogen fixation and nitrogen isotope abundances in zooplankton of the oligotrophic North Atlantic Ocean, Limnol. Oceanogr., 47, 1617 1628, 2002b.

Montoya, J. P., Holl, C. M., Zehr, J. P., Hansen, A., Villareal, T. A., and Capone, D. G.: High rates of $\mathrm{N}_{2}$ fixation by unicellular diazotrophs in the oligotrophic Pacific Ocean, Nature, 430, 1027-1031, 2004.

Moore, C. M., Mills, M. M. M., Arrigo, K. R., Berman-Frank, I., Bopp, L., Boyd, P. W., Galbraith, E. D., Geider, R. J., Guieu, C., Jaccard, S. L., Jickells, T. D., La Roche, J., Lenton, T. M., Mahowald, N. M., Maranon, E., Marinov, I., Moore, J. K., Nakatsuka, T., Oschlies, A., Saito, M. A., Thingstad, T. F., Tsuda, A., and Ulloa, O.: Processes and patterns of oceanic nutrient limitation, Nat. Geosci., 6, 701-710, 2013.

Moutin, T., Thingstad, T. F., Van Wambeke, F., Marie, D., Slawyk, G., Raimbault, P., and Claustre, H.: Does competition for nanomolar phosphate supply explain the predominance of the cyanobacterium Synechococcus?, Limnol. Oceanogr., 47, 15621567, 2002.

Moutin, T., Van Den Broeck, N., Beker, B., Dupouy, C., Rimmelin, P., and LeBouteiller, A.: Phosphate availability controls Trichodesmium spp. biomass in the SW Pacific ocean, Mar. Ecol.-Prog. Ser., 297, 15-21, 2005.

Moutin, T., Karl, D. M., Duhamel, S., Rimmelin, P., Raimbault, P., Van Mooy, B. A. S., and Claustre, H.: Phosphate availability and the ultimate control of new nitrogen input by nitrogen fix- 
ation in the tropical Pacific Ocean, Biogeosciences, 5, 95-109, doi:10.5194/bg-5-95-2008, 2008.

Mulholland, M. R.: The fate of nitrogen fixed by diazotrophs in the ocean, Biogeosciences, 4, 37-51, doi:10.5194/bg-4-37-2007, 2007.

Mulholland, M. R. and Bernhardt, P. W.: The effect of growth rate, phosphorus concentration, and temperature on $\mathrm{N}_{2}$ fixation, carbon fixation, and nitrogen release in continuous cultures of Trichodesmium IMS101, Limnol. Oceanogr., 50, 839-849, 2005.

Mulholland, M. R. and Capone, D. G.: The nitrogen physiology of the marine N-2-fixing cyanobacteria Trichodesmium spp., Trends Plant Sci., 5, 148-153, 2000.

Mulholland, M. R., Bronk, D. A., and Capone, D. G.: $\mathrm{N}_{2}$ fixation and regeneration of $\mathrm{NH}_{4}^{+}$and dissolved organic $\mathrm{N}$ by Trichodesmium IMS101, Aquat. Microb. Ecol., 37, 85-94, 2004.

Mulholland, M. R., Bernhardt, P. W., Heil, C. A., Bronk, D. A., and O'Neil, J. M.: Nitrogen fixation and regeneration in the Gulf of Mexico, Limnol. Oceanogr., 51, 176-177, 2006.

Nelson, D. M., Tréguer, P., Brzezinski, M. A., Leynaert, A., and Quéguiner, B.: Production and dissolution of biogenic silica in the ocean: Revised global estimates, comparison with regional data and relationship to biogenic sedimentation, Global Biogeochem. Cy., 9, 359-372, doi::10.1029/95GB01070, 1995.

Ohlendieck, U., Gundersen, K., Meyerhöfer, M., Fritsche, P., Nachtigall, K., and Bergmann, B.: The significance of nitrogen fixation to new production during early summer in the Baltic Sea, Biogeosciences, 4, 63-73, doi:10.5194/bg-4-63-2007, 2007.

Ohki, K.: A possible role of temperate phage in the regulation of Trichodesmium, Bull. Inst. Oceanogr. Monaco, 19, 235-256, 1999.

O'Neil, J. and Roman, M. R.: Grazers and Associated Organisms of Trichodesmium, in: Marine Pelagic Cyanobacteria: Trichodesmium and other Diazotrophs, edited by: Carpenter, E. J., Capone, D. G., and Rueter, J. G., NATO ASI Series, Springer Netherlands, 1992.

O'Neil, J. M.: Grazer interactions with nitrogen-fixing marine Cyanobacteria: adaptation for $\mathrm{N}$-acquisition?, Bulletins de l'Institut Océanographique de Monaco, 19, 293-317, 1999.

O'Neil, J. M., Metzler, P., and Glibert, P. M.: Ingestion of ${ }^{15} \mathrm{~N}_{2}$ labelled Trichodesmium, and ammonium regeneration by the pelagic harpacticoid copepod Macrosetella gracilis, Mar. Biol., 125, 89-96, 1996.

Ouillon, S., Douillet, P., Lefebvre, J. P., Le Gendre, R., Jouon, A., Bonneton, P., Fernandez, J. M., Chevillon, C., Magand, O., Lefèvre, J., Le Hir, P., Laganier, R., Dumas, F., Marchesiello, P., Bel Madani, A., Andréfouët, S., Panché, J. Y., and Fichez, R.: Circulation and suspended sediment transport in a coral reef lagoon: The south-west lagoon of New Caledonia, Mar. Pollut. Bull., 61, 269-276, 2010.

Pfreundt, U., Spungin, D., Bonnet, S., Berman-Frank, L., and Hess, W. R.: Global analysis of gene expression dynamics within the marine microbial community during the VAHINE mesocosm experiment in the South West Pacific, Biogeosciences Discuss., doi:10.5194/bg-2015-564, in review, 2016a.

Pfreundt, U., Van Wambeke, F., Caffin, M., Bonnet, S., and Hess, W. R.: Succession within the prokaryotic communities during the VAHINE mesocosms experiment in the New Caledonia lagoon, Biogeosciences, 13, 2319-2337, doi:10.5194/bg-13-2319-2016, 2016 b.
Rodier, M. and Le Borgne, R.: Population dynamics and environmental conditions affecting Trichodesmium spp. (filamentous cyanobacteria) blooms in the south-west lagoon of New Caledonia, J. Exp. Mar. Biol. Ecol., 358, 20-32, 2008.

Rodier, M. and Le Borgne, R.: Population and trophic dynamics of Trichodesmium thiebautii in the SE lagoon of New Caledonia, Comparison with T. erythraeum in the SW lagoon, Mar. Pollut. Bull., 61, 349-359, 2010.

Scharek, R. M., Latasa, M., Karl, D. M., and Bidigare, R. R.: Temporal variations in diatom abundance and downward vertical fux in the oligotrophic North Pacific gyre, Deep-Sea Res. Pt. I, 46, 1051-1075, 1999a.

Sharek, R. M., Tupas, L. M., and Karl, D. M.: Diatom fluxes to the deep sea in the oligotrophic North Pacific gyre at Station ALOHA, Mar. Ecol.-Prog. Ser., 82, 55-67, 1999b.

Sipler, R. A., Bronk, D. A., Seitzinger, S. P., Lauck, R. J., McGuinness, L. R., Kirkpatrick, G. J., Heil, C. A., Kerkhof, L. J., and Schofield, O. M.: Trichodesmium-derived dissolved organic matter is a source of nitrogen capable of supporting the growth of toxic red tide Karenia brevis, Mar. Ecol.-Prog. Ser., 483, 31-45, 2013.

Slawyk, G. and Raimbault, P.: Simple procedure for simultaneous recovery of dissolved inorganic and organic nitrogen in ${ }^{15} \mathrm{~N}$ tracer experiments and improving the isotopic mass balance, Mar. Ecol.-Prog.Ser., 124, 289-299, doi:10.3354/meps124289, 1995.

Sommer, S., Hansen, T., and Sommer, U.: Transfer of diazotrophic nitrogen to mesozooplankton in Kiel Fjord, Western Baltic Sea: a mesocosm study, Mar. Ecol.-Prog. Ser., 324, 105-112, 2006.

Spungin, D., Pfreundt, U., Berthelot, H., Bonnet, S., AlRoumi, D., Natale, F., Hess, W. R., Bidle, K. D., and Berman-Frank, I.: Mechanisms of Trichodesmium demise within the New Caledonian lagoon during the VAHINE mesocosm experiment, Biogeosciences, 13, 4187-4203, doi:10.5194/bg-13-4187-2016, 2016.

Subramaniam, A., Yager, P. L., Carpenter, E. J., Mahaffey, C., Björkman, K., Cooley, S., Kustka, A. B., Montoya, J. P., SañudoWilhelmy, S. A., Shipe, R., and Capone, D. G.: Amazon River enhances diazotrophy and carbon sequestration in the tropical North Atlantic Ocean P. Natl. Acad. Sci. USA, 105, 10460 10465, doi:10.1073/pnas.0710279105, 2008.

Torréton, J.-P., Rochelle-Newall, E., Pringault, O., Jacquet, S., Faure, V., and Briand, E.: Variability of primary and bacterial production in a coral reef lagoon (New Caledonia), Mar. Pollut. Bull., 61, 335-348, 2010.

Turk-Kubo, K. A., Frank, I. E., Hogan, M. E., Desnues, A., Bonnet, S., and Zehr, J. P.: Diazotroph community succession during the VAHINE mesocosm experiment (New Caledonia lagoon), Biogeosciences, 12, 7435-7452, doi:10.5194/bg-12-7435-2015, 2015.

Van Wambeke, F., Pfreundt, U., Barani, A., Berthelot, H., Moutin, T., Rodier, M., Hess, W. R., and Bonnet, S.: Heterotrophic bacterial production and metabolic balance during the VAHINE mesocosm experiment in the New Caledonia lagoon, Biogeosciences, 13, 3187-3202, doi:10.5194/bg-13-3187-2016, 2016.

Walsby, A. E.: The gas vesicles and buoyancy of Trichodesmium, Marine Pelagic Cyanobacteria: Trichodesmium and other Diazotrophs, 141-161, 1992. 
Wannicke, N., Korth, F., Liskow, I., and Voss, M.: Incorporation of diazotrophic fixed $\mathrm{N}_{2}$ by mesozooplankton - Case studies in the southern Baltic Sea, J. Mar. Sys., 117-118, 1-13, 2013.

White, A. E., Foster, R. A., Benitez-Nelson, C. R., Masqué, P., Verdeny, E., Popp, B. N., Arthur, K. E., and Prahl, F. G.: Nitrogen fixation in the Gulf of California and the Eastern Tropical North Pacific, Prog. Oceanogr., 109, 1-17, 2012.
Yeung, L. Y., Berelson, W., Young, E. D., Prokopenko, M. G., Rollins, N., Coles, V. J., Montoya, J. P., Carpenter, E. J., Steinberg, D. K., Foster, R. A., Capone, D. G., and Yager, P. L.: Impact of diatom-diazotroph associations on carbon export in the Amazon River plume, Geophys. Res. Lett., 39, L18609, doi:10.1029/2012GL053356, 2012. 